\title{
Quality and Equity in Education
}

Quality and Equity in Education draws attention to the importance of developing and testing theories of educational effectiveness and using these theories for improvement purposes. It makes a major contribution to knowledge and theory building in research on promoting quality and equity in education.

The book presents an improved version of the dynamic model of educational effectiveness based on the empirical data emerged from studies testing its validity, claiming that the proposed theory can be used for establishing links between educational effectiveness research and school improvement. Towards that end, the book presents the Dynamic Approach to teacher and school improvement, demonstrating its impact on quality and equity in education. The book not only proposes an agenda for further research on developing and testing the dynamic theory of educational effectiveness but also refers to research methods that can be used to test the assumptions of this theory and search for relevant cause and effect relations. The agenda also refers to the need of identifying the conditions under which the dynamic approach to teacher and school improvement can have an effect on student learning outcomes.

This book will be of great interest for academics, researchers and postgraduate students working in education research and the area of quality and equity in education. It will also be of interest to policymakers, school advisors and other stakeholders in education.

Leonidas Kyriakides is Professor in Educational Research and Evaluation and the Head of the Department of Education at the University of Cyprus.

Hubertus (Bert) P.M. Creemers is Professor Emeritus at the University of Groningen in the Netherlands.

Anastasia Panayiotou is a postdoctoral researcher at the Department of Education of the University of Cyprus.

Evi Charalambous is a doctoral researcher and special scientist (research) at the Department of Education of the University of Cyprus. 


\section{Routledge Research in Education}

This series aims to present the latest research from right across the field of education. It is not confined to any particular area or school of thought and seeks to provide coverage of a broad range of topics, theories and issues from around the world.

Recent titles in the series include:

Pedagogy in the Novels of J.M. Coetzee

The Affect of Literature

Aparna Mishra Tarc

Integrative and Interdisciplinary Curriculum in the Middle School

Integrated Approaches in Teacher Preparation and Practice.

Edited by Lisa M Harrison, Ellis Hurd, and Kathleen Brinegar

The Generation of Utopia

Decolonizing Critical Curriculum Theory

João M. Paraskeva

Sport, Physical Education, and Social Justice

Religious, Sociological, Psychological, and Capability Perspectives

Edited by Nick J. Watson, Grant Jarvie and Andrew Parker

Quality and Equity in Education

Revisiting Theory and Research on Educational Effectiveness and Improvement

Leonidas Kyriakides, Bert P.M. Creemers, Anastasia Panayiotou, \& Evi Charalambous

For a complete list of titles in this series, please visit www.routledge.com/ Routledge-Research-in-Education/book-series/SE0393 


\section{Quality and Equity in Education}

Revisiting Theory and Research on Educational Effectiveness and Improvement

Leonidas Kyriakides, Bert P.M. Creemers, Anastasia Panayiotou, \& Evi Charalambous 
First published 2021

by Routledge

2 Park Square, Milton Park, Abingdon, Oxon OX14 4RN

and by Routledge

52 Vanderbilt Avenue, New York, NY 10017

Routledge is an imprint of the Taylor \& Francis Group, an informa business

(C) 2021 Leonidas Kyriakides, Bert P.M. Creemers, Anastasia

Panayiotou, \& Evi Charalambous

The right of Leonidas Kyriakides, Bert P.M. Creemers, Anastasia

Panayiotou, \& Evi Charalambous to be identified as authors of

this work has been asserted by them in accordance with sections 77 and 78 of the Copyright, Designs and Patents Act 1988.

All rights reserved. No part of this book may be reprinted or reproduced or utilised in any form or by any electronic, mechanical, or other means, now known or hereafter invented, including photocopying and recording, or in any information storage or retrieval system, without permission in writing from the publishers.

Trademark notice: Product or corporate names may be trademarks or registered trademarks, and are used only for identification and explanation without intent to infringe.

British Library Cataloguing-in-Publication Data

A catalogue record for this book is available from the British Library

Library of Congress Cataloging-in-Publication Data

A catalog record for this book has been requested

ISBN: 978-1-138-30180-1 (hbk)

ISBN: 978-0-203-73225-0 (ebk)

Typeset in Galliard

by Apex CoVantage, LLC 


\section{Contents}

List of figures vii

List of tables viii

Preface $x$

1 Quality and equity in education 1

PART 1

Developing and testing educational effectiveness theories

2 Educational effectiveness theories: moving from single approaches to integrated models

3 Theories of educational effectiveness addressing the dynamic nature of education

4 Developing and testing the dynamic theory of educational effectiveness: a systematic review

PART 2

Approaches to school improvement and their impact on quality and equity in education

5 Different approaches to school improvement: the value of an evidence-based and theory-driven approach

6 The dynamic approach to teacher and school improvement

7 Effects of different approaches to teacher and school improvement on promoting student learning outcomes 


\section{PART 3}

Educational effectiveness and improvement: broadening the agenda

8 Establishing the 2020 version of the dynamic model and expanding the dynamic approach to promote quality and equity in education

9 Developing, testing and using theories of educational effectiveness to promote quality and equity in education: implications for research, policy and practice

References

Index 


\section{Figures}

1.1 Dimensions of measuring educational effectiveness concerned with outcomes of schooling

2.1 The comprehensive model of educational effectiveness 39

3.1 The dynamic model of educational effectiveness 51

3.2 Factors of the dynamic model operating at the student level 58

3.3 Factors of the dynamic model operating at the classroom level 63

3.4 Factors of the dynamic model operating at the school level 69

3.5 Factors of the dynamic model operating at the system level $\quad 74$

6.1 The major steps in the dynamic approach to teacher and school improvement

6.2 Developmental stages of teaching skills 165

8.1 The main structure of the 2020 version of the dynamic model 218

8.2 Factors of the 2020 version of the dynamic model operating at the student level

8.3 Factors of the 2020 version of the dynamic model operating at the school level 


\section{Tables}

2.1 School-level factors and formal principles operating in generating effectiveness according to the comprehensive model of educational effectiveness

3.1 The main elements of each teacher factor included in the dynamic model

4.1 Empirical evidence supporting the main assumptions of the dynamic model emerging from empirical studies and meta-analyses

4.2 The five developmental stages of teaching skills included in the dynamic model

4.3 An overview of the studies conducted in different countries which were able to test the main assumptions of the dynamic model regarding factors operating at classroom level

4.4 The four stages of teachers' assessment skills

4.5 Number of studies investigating the effect of each factor included in the dynamic model, number of studies which managed to identify statistically significant effect(s) of this factor (and in parentheses the total number of significant effects that emerged), number of studies which identified at least one insignificant effect (and in parentheses the total number of nonsignificant effects that emerged) as well as characteristics of studies identifying significant effects concerned with the type of learning outcome considered and the age group of the student sample

4.6 Number of studies investigating the effect of factors not included in the dynamic model, number of studies which managed to identify statistically significant effect(s) of each factor (and in parentheses the total number of significant effects that emerged), number of studies which identified at least one insignificant effect (and in parentheses the total number of nonsignificant effects that emerged) as well as characteristics of studies identifying significant effects concerned with the type of learning outcome considered and the age group of the student sample 
7.1 An overview of projects which made use of the DA for teacher improvement purposes

7.2 An overview of projects which made use of the DA for school improvement purposes

7.3 Number of teacher and school improvement studies per study characteristic concerning: a) the participating countries; b) the period in which the study was conducted; c) the age group of participating students (i.e., phase of schooling); d) the type of learning outcomes considered; e) the approach of each intervention; f) the type of support provided for teachers and other school stakeholders; g) the research design of each study

7.4 Number of studies per factor addressed by each teacher and school intervention, number of studies searching for effects on the factor addressed, number of studies which managed to identify at least one statistically significant effect of the intervention on: a) the factor addressed; b) any type of student learning outcome (and in parentheses the number of significant effects identified out of those which were examined); c) cognitive learning outcomes; d) non-cognitive learning outcomes

8.1 The main elements of each dimension of the updated version of the dynamic model, including the ways that can be used to measure each dimension and the assumption about its impact on student learning outcomes

8.2 Implications of the main assumptions of the dynamic approach for the design of teacher and school improvement interventions 


\section{Preface}

Twelve years ago, two of us published the first results of our joint efforts in the development of a dynamic perspective on educational effectiveness. In the last section of that book, it was claimed that our proposed dynamic model could not only be used for research and theoretical purposes, but could also contribute to the promotion of the improvement of education. In this respect, we argued for the need to establish an evidence-based and theory-driven approach to teacher and school improvement. To achieve this aim, we first of all conducted several national and international studies to test the main assumptions of the dynamic model and determine the impact of the factors included in the model on student learning outcomes. These studies generated some empirical support for the early version of the dynamic model, especially at the classroom and school levels. Our next step was to develop a specific approach to promoting quality in education, which is not only in line with the main findings of educational effectiveness research, but also takes into account the major lessons that have emerged from research on school improvement. Eight years ago, we published a book in which we proposed the use of a dynamic approach to school improvement that would attempt to contribute to the establishment of the merging of traditions of educational effectiveness research with school improvement efforts. During the last decade, evidence supporting the importance of employing the dynamic approach for teacher and school improvement purposes emerged from national and international experimental studies. However, the studies on using the dynamic model to develop an improvement approach were mainly concerned with the quality dimension of effectiveness. In this respect, a book arguing for the importance of promoting not only quality but also equity in education has recently been published by our research team. During the last five years, longitudinal studies exploring the relationship between the two dimensions of effectiveness and experimental studies concerning the use of the dynamic approach for promoting both quality and equity were also conducted.

After almost two decades of work on developing and testing a dynamic theory of educational effectiveness and on using this theory to develop an improvement approach and later on to test its impact on promoting both quality and equity, we are publishing a book that provides an overview of the main lessons that 
have emerged from our journey. The lessons arising from the empirical studies that tested the dynamic model and from the studies that investigated the impact of the dynamic approach enabled us to propose an updated version of the dynamic model, which is presented in this book. We also made use of this work in order to propose an expanded version of the dynamic approach to teacher and school improvement. Therefore, the principal objective of this book is to make a major contribution to knowledge and theory building with respect to research on the promotion of quality and equity in education. The book is split into three parts.

In the first part of our book, we refer to recent theoretical developments in the field of educational effectiveness and argue for the importance of considering the dynamic nature of education. The assumptions and main elements of the dynamic model of educational effectiveness are presented. In the last chapter of this part, we refer to the empirical support that the dynamic model has received and present the results of a review of recent effectiveness studies, which have helped us to identify ways to improve the dynamic model further.

The second part provides an overview of research on school improvement and argues for the importance of using an evidence-based and theory-driven approach. In this context, the rationale and main features of the dynamic approach to school improvement are presented. We then refer to studies investigating the added value of using this dynamic approach in order to promote quality and equity. By presenting these studies, the readers are provided with concrete examples of school improvement strategies and action plans, which were developed by making use of this approach. We also demonstrate how this approach has been put into practice in different contexts and discuss the possibilities of establishing stronger links between theories of educational effectiveness and research on school improvement. In the last chapter of this part, we also present the main results of a synthesis of improvement studies, which reveal the importance of identifying the conditions under which the dynamic approach can be used for improvement purposes.

In the last part of the book, we propose a broadening of the research agenda on educational effectiveness and improvement and claim that research on developing and testing theories of educational effectiveness can contribute significantly to the establishment of an approach to teacher and school improvement that can make a major contribution to the promotion of quality and equity in education. Specifically, an improved version of the dynamic model is proposed, taking into consideration the results of studies that tested the validity of the model as well as the findings of a synthesis of effectiveness studies conducted during the last 12 years. We also propose ways of elaborating further the dynamic approach to teacher and school improvement and refer to the role of all stakeholders within an educational system (from parents to policy-makers) in promoting quality and equity in education. Implications for research, policy and practice are finally outlined in the last chapter of the book. In this way, the importance of merging the field of educational effectiveness with those of teacher and school improvement is stressed. 
In the writing of this book, we received support from many colleagues, professionals in schools and our families. We would like to make a special mention of some of them. The research assistants in our research group, and especially our postdoctoral researchers Andria Dimosthenous, Elena Kokkinou and Margarita Christoforidou and our PhD students Ioannis Ioannou, Maria Anastasou and Tryfonas Papadamou provided us with comments from the perspective of young researchers in the field of educational effectiveness and improvement. Moreover, Sheila M. Hakin not only supported us in the process of linguistic editing, but she was also critical in helping us to clarify the meaning of the book. Finally, our universities were supportive in facilitating our academic efforts to write the book. We should like to thank them all for their help, and we hope that they will be pleased with the final product. Of course, any mistakes that remain are ours.

This book can be seen as the end product of the first phase of a journey that started almost 20 years ago, aiming not only to develop and test a theory on educational effectiveness that takes into account the dynamic nature of education, but also to gradually establish an evidence-based and theory-driven approach to the promotion of both quality and equity in education. We welcome comments, criticism and contributions to the further development of research on educational effectiveness and improvement from readers with different perspectives on education. We hope that you can join us in our journey to make education effective and more equitable. 


\section{Quality and equity in education}

\section{Aims and outline of Chapter 1}

The principal objective of this book is to make a major contribution to knowledge and theory-building in research on the promotion of quality and equity in education. The book draws attention to the importance not only of developing and testing theories of educational effectiveness, but also of using these theories for improvement purposes. For this reason, in the first part of this book, we refer to recent theoretical developments in the field of educational effectiveness and argue for the importance of taking into consideration the dynamic nature of education. The assumptions and main elements of the dynamic model of educational effectiveness are presented. In the last chapter of the second part page, we refer to the empirical support that this model has received and present the results of a review of recent effectiveness studies, which help us identify ways to improve this model further. In the second part of the book, we discuss the extent to which links between Educational Effectiveness Research (EER) and research on school improvement can be established. Thus, the rationale and the main features of the Dynamic Approach (DA) to teacher and school improvement are presented. We then refer to studies testing the impact of the DA on the promotion of quality and equity. In the last chapter of this part, we also present the main results from a synthesis of improvement studies, which reveal the importance of identifying the conditions under which the DA can be used for improvement purposes. In the last part of the book, we propose a broadening of the agenda of research on educational effectiveness and improvement and claim that research on developing and testing theories of educational effectiveness can contribute significantly to establishing an effective approach to school improvement that can have a major impact on promoting quality and equity in education. Specifically, an improved version of the dynamic model is proposed, taking into consideration the results of studies testing the validity of the model as well as the results of a relevant synthesis of effectiveness studies conducted during the fourth phase of EER. In the last part, we also propose ways to elaborate further this DA to teacher and school improvement by considering the results of a relevant synthesis of recent teacher and 


\section{Quality and equity in education}

school improvement studies conducted during the last 12 years (i.e., 20052017). Implications for research, policy and practice are finally drawn in the last chapter of the book. In this way, we reveal the importance of merging the field of educational effectiveness with the fields of teacher and school improvement. We initially present a review of theories and studies of effectiveness and improvement in two different parts of the book, but readers will see how research on effectiveness (presented in Part 1 ) is used to build a specific approach to improvement (presented in Part 2). In the last part, readers will also learn how research on improvement can help develop further the theoretical framework of EER and therefore that treating the fields of effectiveness and improvement separately is not productive. In the last part, we therefore argue that the ultimate aim of researchers in the field of effectiveness and improvement should be the promotion of quality and equity in education, and this can be achieved not only by developing further the theoretical framework of educational effectiveness, but also by using research findings to establish an evidence-based and theory-driven approach to teacher and school improvement.

In this introductory chapter, we discuss the importance of promoting both quality and equity in education for the benefit of individual students and the society. We point out that there are different views on what is socially just and how equity in education can be measured. We then claim that these views of equity can be divided into two broad categories: a meritocratic and an egalitarian view. Thus, in this chapter, the main arguments/assumptions of each of these two views are presented. In the third part of the chapter, we discuss the relationships between quality and equity in education and show that a number of researchers in the fields of psychology, sociology and economics of education have treated quality and equity as being in competition with each other and have supported different approaches to how to deal with the 'cost' of promoting the one rather than the other. This debate has arisen because the two dimensions of effectiveness (quality and equity) have never been explicitly defined, and consequently there is not enough research that has investigated the relationship between the two dimensions of effectiveness in classrooms, schools and educational systems; the result is a lack of evidence. Thus, we provide clear definitions of the concepts of quality and equity in relation to what schools can do to promote these two dimensions of effectiveness. We also argue for the importance of investigating the relationships between quality and equity and compare the effectiveness status of teachers, schools and educational systems in relation to these two dimensions. In the last section of this chapter, we argue for the importance not only of developing theories that can explain variation in educational effectiveness in terms of quality and/or equity, but also of using theories for improvement purposes. In this respect, we refer to the findings of research on differential educational effectiveness, which reveal that teachers and schools can achieve both quality and equity. Finally, the aims of the book and its structure are outlined. 


\section{Promoting quality and equity: the main purpose of education}

Education is a powerful tool for improving all aspects of a person's life and a factor in the reduction of poverty (Kyriakides, Creemers, \& Charalambous, 2018). School failure can have a negative long-lasting impact on a child's life, since leaving school without enough qualifications may result in finding a lowincome job and having a poorer lifestyle, which may not allow equal participation in the civic and social aspects of modern society in comparison with children attending education for a longer period of time (Micklewright \& Schnepf, 2007). Based on data from the Programme for International Student Assessment (PISA), it is estimated that if all 15-year-olds in the area of the Organisation for Economic Co-operation and Development (OECD) attained at least level 2 in the PISA mathematics assessment, they would contribute over USD 200 trillion in terms of additional economic output over the course of their working lives (OECD, 2010a). Thus, educational failure results in high costs for society since uneducated people cannot be actively involved in civic and political affairs and are more prone to crime, other illegal activities (OECD, 2010b; OECD, 2013; Torney-Purta, Lehmann, Oswald, \& Schulz, 2001), and unhealthy habits, as they may face both economic and social problems (Cunha \& Heckman, 2009; Heckman, 2008; Psacharopoulos, 2007). However, children are not all equal when it comes to educational failure. Evidence shows that children coming from socially disadvantaged homes are more likely to have worse school results and to drop out of school more frequently than are children coming from better-off families. For example, international evaluation studies like PISA have revealed that in Europe approximately 20 per cent of students are not equipped with basic skills in mathematics and that a 15-year-old student from a relatively disadvantaged home is 2.37 times more likely to be a poor performer (obtaining a score below level 2 that measures basic skills in mathematics) than is a student from an affluent family (see OECD, 2012). Meta-analyses have also revealed that the socioeconomic status (SES) of students has an impact on student achievement (Sirin, 2005; White, 1982). Therefore, socioeconomic inequalities in education are an important issue for both researchers and policy-makers, and all agree that in a democratic society socioeconomic inequalities in educational outcomes should be minimal (Kyriakides \& Creemers, 2018; Marks, Cresswell, \& Ainley, 2006). Consequently, one of the major objectives of the education systems around the world is to understand which are the schooling processes that provide opportunities for all learners to succeed in school (Frempong, Reddy, \& Kanjee, 2011) and thereby promote both quality and equity in education (Kyriakides \& Creemers, 2011). To achieve this objective, not only should schools within these systems help students achieve learning outcomes, but they also need to function in such a way that students' success in learning is not determined by the characteristics of their background.

At this point, it should be acknowledged that there are different visions of how equity in education can be defined (Atkinson, 2015; Paquette, 1998), 


\section{Quality and equity in education}

which can generally be divided into two broad categories: a) a meritocratic view and b) an egalitarian view. The meritocratic view is based on the assumption that 'status' in society should be the reflection of one's own 'merits', 'talents' and 'effort' (Gulson \& Webb, 2012; McCoy \& Major, 2007). According to this view, differences in student learning outcomes may be attributed to differences between students in terms of their cognitive abilities, talents and amount of work dedicated to schooling (i.e., the effort they put in, in order to succeed). However, EER reveals that student learning outcomes are associated with various student factors, including background factors, such as SES, gender and ethnicity, which are given characteristics and which students are not in a position to change easily in order to achieve better learning outcomes. In the first part of this book, we explicitly refer to the main findings of EER and present theoretical models of EER that take into account the impact of student factors (see Chapters 2 and 3). This implies that even if students are provided with the same learning opportunities, variation in student learning achievement gains can be detected, and this variation can partly be explained by student background factors beyond their cognitive abilities and the effort that they put in to achieve these outcomes (Kyriakides \& Luyten, 2009; Lim, 2013).

In this book, we argue that even if students are given the same opportunities within the school, not all students will manage to develop their talents since different hidden mechanisms in society, as well as differences in their home learning environment, will also affect their progress (see also Sammons, Toth, \& Sylva, 2018). Based on the work of these critics and research findings, the egalitarian vision has evolved to become the mainstream view of equity, which implies that the main responsibility for achieving equity should be that of society (Van Damme \& Bellens, 2017). In the case of education, national/state agencies and schools are expected to provide further support for those disadvantaged groups of students (based on their background characteristics, such as SES, gender and ethnicity) in order to ensure that differences in learning outcomes are substantially reduced (Kelly \& Downey, 2010; OECD, 2012). This implies that positive discrimination of different groups is not only legitimated in order to obtain equity in education, but also seen as a characteristic of effective education (Kyriakides, Creemers, \& Charalambous, 2018).

In this chapter, we therefore claim the importance of using two dimensions in measuring educational effectiveness. Specifically, we argue that effective educational systems, schools and teachers are not only those that contribute to the promotion of learning outcomes for all (quality), but also those that manage to reduce differences in student learning outcomes between groups of students with different background characteristics (equity). At the same time, it is acknowledged that differences in learning outcomes between different groups of students cannot be completely eliminated since these gaps can be attributed to other hidden mechanisms in society over which schools may have no control. In this way, we follow the same approach to measuring equity as we do to measuring quality, whereby we expect to see progress on the part of all students but do not anticipate that all of them will achieve the 'same maximum' results. 


\section{Measuring quality and equity at classroom/school/ system level: the two dimensions of educational effectiveness}

Work on equal educational opportunities conducted 50 years ago by Coleman and his colleagues (Coleman et al., 1966) and Jencks and his colleagues (Jencks et al., 1972) argued that student achievement can be predicted mainly on the basics of the background characteristics of students and especially their SES and their intelligence. These studies claimed that after controlling for student background factors, not much variation in student achievement remains to be explained by the influence of teachers and schools. These findings resulted in a pessimistic view of the contribution that teachers and schools can make in promoting student learning outcomes. In this context, two studies conducted independently in the USA (Brookover, Beady, Flood, Schweitzer, \& Wisenbaker, 1979) and the UK (Rutter, Maughan, Mortimore, Ouston, \& Smith, 1979) were concerned with examining evidence demonstrating the impact that teachers and schools can have on promoting student learning outcomes. As a consequence, early school effectiveness research and school improvement projects were underpinned, to a greater or lesser extent, by the idea of creating effective schools for the urban poor (Edmonds, 1979). In the 1980s, there was quite a lot of criticism levelled against this kind of school improvement and research because of its conspicuous sampling biases (Firestone \& Herriott, 1982; Purkey \& Smith, 1983; Ralph \& Fennessey, 1983; Rowan, Bossart, \& Dwyer, 1983). As a result, during the last four decades, various large-scale effectiveness studies have been conducted in several countries demonstrating the impact that teachers and schools can have in promoting student learning outcomes. Moreover, accountability systems have been developed in several countries, which treat the progress made by students as the main criterion for evaluating teachers and schools (Ray, 2006; Sanders \& Horn, 1994). Furthermore, the great majority of effectiveness studies conducted in various countries have revealed that, after controlling for student background factors, a lot of variation at the school level remains (Chapman, Muijs, Reynolds, Sammons, \& Teddlie, 2016; Townsend, 2007), and the variation that is left unexplained is treated as an indicator of the school effect on student learning outcomes (Goldstein, 2003; Thomas, Peng, \& Gray, 2007). As a consequence, there is nowadays substantial agreement as to appropriate methods of estimating school differences or effects and the kinds of data required for valid comparisons to be made in relation to the promotion of quality (Creemers, Kyriakides, \& Sammons, 2010; Dumay, Coe, \& Anumendem, 2014; Goldstein, 1997).

With regard to the impact of teachers and schools on equity, some effectiveness studies have revealed that teachers and schools matter most for underprivileged and/or initially low-achieving students (Scheerens \& Bosker, 1997). This implies that schools which are effective in terms of the quality dimension may also be effective in reducing the learning differences between students coming from different socioeconomic backgrounds. However, almost all 


\section{Quality and equity in education}

effectiveness studies measure school effectiveness in relation to the quality dimension (Sammons, 2010), and therefore a methodology to measure the impact of schools in promoting equity has not yet been clearly developed (Kelly, 2012; Nachbauer \& Kyriakides, 2020). Nevertheless, during the last decade an emphasis on investigating equity has gradually developed. Kyriakides and his colleagues (Kyriakides, Creemers, \& Charalambous, 2018) refer to the importance of establishing a clear methodology for measuring equity and propose a specific approach that can be used for investigating the relations between the two dimensions of effectiveness: quality and equity. More specifically, equity is seen as being related to fairness, which implies that personal or socioeconomic characteristics, such as gender, ethnic origin or family background, should not be obstacles to success in education. This approach seems to be in line with the indicator for measuring equity at the country level proposed by the OECD, which is concerned with the impact that SES has on student achievement. It is argued that equitable educational systems are those in which SES has a relatively small effect on student learning outcomes. One could therefore evaluate teachers, schools and systems (as well as interventions) by investigating the extent to which the effect of SES on achievement has been 'reduced' during a school year. This implies that effective teachers and schools should not only be able to promote student learning outcomes, but also to contribute to the 'reduction' of the effect on student achievement of student background factors, which are given characteristics and which students are not usually able to change (e.g., SES, gender, ethnicity). It is also important to note here that a multidimensional approach to measuring equity can also be promoted since some schools and/or teachers may be found to be effective in terms of equity when a specific background factor is examined (e.g., SES) but not when another such factor is taken into account (e.g., gender). This assumption has received some empirical support through the analysis of data that have emerged from national and international studies (see Kyriakides, Creemers, \& Charalambous, 2019).

In this chapter, it is also acknowledged that equity in education could be examined in two ways that are closely linked and might help us analyse the implications of school failure for teachers/schools/systems: equity as fairness and equity as inclusion. Specifically, school failure can be seen to be twofold in nature. On the one hand, it could be viewed as the failure of an educational system which is unable to provide an education of quality for all. In this case, overcoming school failure implies ensuring inclusion by providing a basic minimum standard of education for each and every student. Secondly, school failure can be attributed to the fairness perspective, which is based on the fact that factors beyond those that students can control are associated with student learning outcomes. Fairness implies ensuring that personal and social circumstances should not be an obstacle to educational success, and inclusion implies ensuring a minimum standard of education for all (Field, Kuczera, \& Pont, 2007). In this book, we focus on equity as fairness, which may be used to evaluate the impact that teachers and schools can have in promoting equity in education. 
Consequently, the equity dimension of effectiveness in education demands that students' expected learning outcomes should depend only on their own efforts and capacity, and not on considerations over which they have no influence (gender, ethnic origin, SES). This implies that teacher/school/system effectiveness status in terms of equity can be measured by looking at the extent to which differences in learning outcomes between groups of students with different background characteristics are reduced. The idea behind this is that education can contribute to social justice and democracy by closing the gap between students with regard to their background, especially the sociocultural status of their family.

\section{The relationship between quality and equity in education: different theoretical orientations}

By introducing two different dimensions with respect to measuring effectiveness, a question that arises is the extent to which teachers/schools/systems can be effective in terms of both quality and equity (Creemers \& Kyriakides, 2015). Based on fundamental knowledge about quality education, effective schools are able to promote the learning of their students but may not be able to make a special impact on the socially disadvantaged students (Kyriakides, 2007). The research concerned with the influence of schools on different groups of students, so-called differential effectiveness research, concludes that those schools that achieve high results in pursuit of educational objectives in general manage to do so for specific groups, but they cannot significantly decrease the variance between students within classrooms (Campbell, Kyriakides, Muijs, \& Robinson, 2004; Teddlie \& Reynolds, 2000). However, research into educational effectiveness reveals that teachers and schools matter most when it comes to underprivileged and/or initially low-achieving students (Kyriakides, 2004; Scheerens \& Bosker, 1997; Vanlaar et al., 2016). This reveals the importance of using both dimensions of effectiveness measurement (as shown in Figure 1.1), quality and equity, in evaluating teachers/schools/systems and in building theoretical models of educational effectiveness, which could involve factors promoting both quality and equity in education.

Even though a group of researchers in the fields of psychology, sociology and economics of education treated quality and equity as being in competition with each other and supported different approaches to how to deal with the 'cost' of promoting the one rather than the other (Whitty, 2001), Kyriakides and his colleagues (Kyriakides, Creemers, \& Charalambous, 2018) attribute the debate about the relationship between the two dimensions of effectiveness to the lack of a clear definition of the two dimensions, especially equity. This has had an effect on the fact that a methodology for how equity in education can be measured has not been developed. As a consequence, there are very few studies that have investigated the effectiveness status of teachers, schools and/or systems in relation to the equity dimension (Kelly, 2012). In this book we argue that this question should be addressed by EER. 


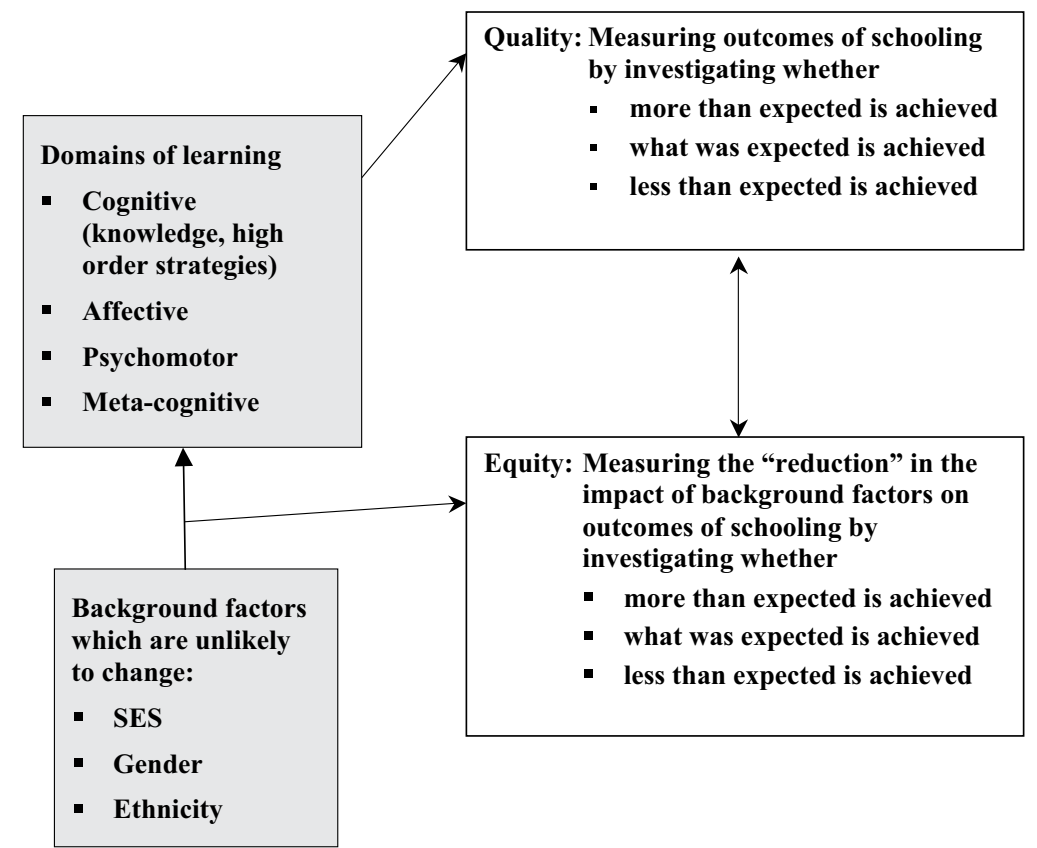

Figure 1.1 Dimensions of measuring educational effectiveness concerned with outcomes of schooling

With its origins in the research on inequality in education, it was evident that EER would examine the educational outcomes of disadvantaged children in particular and search for equity in schools. This meant looking at the extent to which schools were able to compensate for initial differences in defined outcomes (Sammons, 2010). However, most effectiveness studies, while examining the magnitude of teacher and school effects, have paid very little attention to the extent to which teachers and schools perform consistently across different school groupings (Kyriakides, 2007; Scheerens, 2014). As a consequence, the concepts of teacher and school effectiveness have been developed in a generic way by drawing up a one-size-fits-all model (Campbell et al., 2004). Although greater effectiveness may somewhat improve the absolute performance of disadvantaged groups, critics of EER argue it will not improve their relative performance when measured against that of more advantaged groups (Thrupp, 2001). This implies that researchers within the field of EER need to examine further issues dealing with equity in education.

In this context, Kyriakides, Creemers, and Charalambous (2019) have claimed that research into differential teacher and school effectiveness may provide a new perspective in the discussion about educational equity. Fielding (1997, p. 141) acknowledged that the early work of EER provided 'a necessary 
corrective to an overly pessimistic, even deterministic, view of the influence of social and political factors on the efficacy of schools.' Research into differential effectiveness may make progress if it raises issues regarding the development and effective implementation of policy on educational equality (Antoniou \& Griaznova, 2018; Charalambous, Kyriakides, \& Creemers, 2018; Gustafsson, Nilsen, \& Yang Hansen, 2018; Kyriakides \& Creemers, 2018; Sammons et al., 2018; Verhaeghe, Vanlaar, Knipprath, De Fraine, \& Van Damme, 2018). If schools differ significantly in terms of their effectiveness with respect to particular groups of students, issues concerning the extent to which specific factors are associated with school effectiveness in promoting the progress of specific groups of pupils should be examined (Kyriakides, Creemers, \& Charalambous, 2018). In this respect, research on differential teacher treatment of students on the basis of their background characteristics (including SES and prior achievement) has been conducted. These studies seem to reveal that teachers in schools serving relatively high proportions of low-SES students emphasised basic skills more and engaged in more didactic teaching and less constructivist teaching approaches (e.g., Campbell, Kyriakides, Muijs, \& Robinson, 2003; Stipek, 2004). In addition, studies on instructional quality and student background characteristics reveal that classroom inequality within and between schools contributed substantially to achievement gaps that developed during the early school years (e.g., Palardy, 2015; Palardy \& Rumberger, 2008; Xue \& Meisels, 2004). In this context, we argue in this book that the theoretical framework of EER should be expanded to include the identification of factors associated with both the quality and equity dimension of effectiveness. Pinpointing these factors may be useful not only for modelling effectiveness but also for supporting policy-makers and school stakeholders in their attempts to design and implement evidencebased and theory-driven policies on equal opportunities.

This argument about research on modelling effectiveness in terms of both dimensions (quality and equity) is in line with the concerns of the main research question of EER, which relates to 'what works' in education and has led to a combination of research in different areas, such as teacher behaviour, curriculum, grouping procedures, school organisation, and educational policy (Creemers \& Kyriakides, 2008a; Scheerens, 2014). However, as Scheerens (2013, 2016) points out, after addressing this question one should then investigate 'why does it work', in order to interpret the research findings correctly and establish an effectiveness theory. In addition, to address aspects not only of quality, but also of equity in education, one should also examine questions like 'for whom does it work' and 'under which conditions', especially since there are some effectiveness studies which have revealed that schools may matter more for the disadvantaged groups of students and that school effects tend to be more significant for disadvantaged students (Kyriakides, Creemers, \& Charalambous, 2019; Scheerens \& Bosker, 1997). These broad research questions reveal the complexity of generating theoretical models of effectiveness, as well as the importance of examining equity by investigating whether specific factors are more or less effective for specific groups of students. 


\section{Quality and equity in education}

The importance of addressing equity in education was a topic high on the agenda of EER during its first phase, but one that has received less attention over time due to the assumption that by promoting quality, equity may also be achieved (Kyriakides, Creemers, \& Charalambous, 2018). As noted by Gustafsson and his colleagues (2018), very few studies in the area of EER have taken into account both dimensions of effectiveness, even though there are indications that equity is associated with better student outcomes. It is therefore important to develop models that not only consider both dimensions of effectiveness, as is the case with the dynamic model of educational effectiveness (see Chapter 3 ), but also to search for factors which can explain variations in the effectiveness status of teachers/schools/systems in terms of both quality and equity. To support the argument that we need more studies investigating the relationship between quality and equity in education, we briefly refer in the next section of this chapter to recent studies addressing both dimensions of effectiveness. The findings of these studies help us clarify the definitions given to the two dimensions of effectiveness presented in Figure 1.1.

\section{Investigating the relationship between quality and equity in education: main findings and implications for research}

In the previous sections of this chapter, the two dimensions of effectiveness were defined and their importance was discussed. We were also concerned with the importance not only of using both dimensions of effectiveness in evaluating teachers/schools/systems, but also of searching for the relationships between these two dimensions. Finally, it has been argued that due to the lack of systematic research on the relationship between quality and equity, a debate on whether both dimensions can be promoted has emerged. In this section, we refer to the main results of different types of study (i.e., crosssectional, longitudinal, experimental) which have recently been conducted in order to investigate the relationship between quality and equity in education. Based on the findings of these studies, we also draw implications for research on school effectiveness and improvement which are connected with the main aim of this book.

\section{Exploring the relationship between quality and equity: secondary analyses of PISA}

In our recently published book on promoting equity in education (see Kyriakides, Creemers, \& Charalambous, 2018), we present the results of secondary analyses of the various PISA cycles which examined the relationship between quality and equity at the system/country and school levels. Specifically, the assumption that the dimensions of quality and equity at system and/or school level are related to each other was tested by conducting cross-country, multilevel analyses of each PISA cycle to investigate the extent to which the SES gap in student achievement is smaller in schools and countries which have better learning outcomes (after controlling for the effect of SES). In this secondary analysis, 
Kyriakides and his colleagues (Kyriakides, Creemers, \& Charalambous, 2018) only used data on student achievement in the subject that was the focus of each PISA cycle (i.e., reading in 2000 and 2009, mathematics in 2003 and 2012, science in 2006 and 2015). Thus, separate cross-country, multilevel analyses for each PISA cycle were conducted and the data were conceptualised as a threelevel model, consisting of students at the first level, schools at the second level and countries at the third level.

In each PISA cycle, about one quarter of the variance in student achievement was situated at each of the country and school levels, and the indicator of SES concerned with the highest occupational status of parents (i.e., HISEI) was found to explain approximately 10 per cent of the total variance in student achievement. In each PISA cycle, aggregated scores of this indicator of SES (i.e., 'composition effects' of HISEI) were able to explain even more variance than the relevant student-level indicator of SES (additional variance that was explained ranged from approximately 11 per cent to 17 per cent of the total variance). These results seem to be in line with the findings of meta-analyses of studies investigating the SES effects on student achievement which revealed that when researchers used aggregated measures of SES, they reported higher correlations between SES and academic achievement (see Kyriakides, Charalambous, Creemers, \& Dimosthenous, 2019; Sirin, 2005; White, 1982). Finally, a random-slope model was run to find out whether HISEI had any differential 'effect' at the school and/or country level. For each PISA cycle, all parameter estimates of the random part were statistically significant at level .05 . By taking into account the random part at the country level, the correlation between the residual of the intercept and the residual of the slope was estimated and found to be statistically significant (and negative). This implies that the achievement gap (in the three different subjects) based on HISEI tends to be smaller in countries which achieve better learning outcomes (after controlling for HISEI). Similar results emerged from estimating the correlation coefficients of the two residuals at the school level. In all cycles these correlation coefficients were also statistically significant at level .05 (and negative). These findings showed that the achievement gaps based on HISEI were smaller in more effective schools in terms of their overall student achievement (after controlling for the effect of HISEI).

Thus, these cross-country analyses seemed to support the argument that schools and countries in which HISEI had a smaller effect on achievement tended to be more effective than others in terms of achieving better final student learning outcomes. At this point, it is important to note that previous studies have considered only the statistical significance of the variation among schools in terms of SES gaps to evaluate whether schools can play a bridging role (Chudgar \& Luschei, 2009). In this study, in addition to exploring variation in the achievement gap based on the SES indicators across schools/ countries, Kyriakides and his colleagues (Kyriakides, Creemers, \& Charalambous, 2018) also considered their practical significance. This analysis showed relatively small effects, which, however, differed noticeably across schools and countries and need to be considered by researchers in the field of EER in order to contribute not only to the understanding of the nature of effectiveness but 


\section{Quality and equity in education}

also to the promotion of both quality and equity in education. The modest correlation coefficients reported in this study also revealed that achieving better overall student learning outcomes (quality) does not necessarily guarantee the achievement of equity (and vice versa). There were many schools and countries which were found to be more effective in terms of achieving better student learning outcomes after controlling for the effect of HISEI, but less effective in terms of the size of the HISEI gap in student achievement. Therefore, using both ways to measure quality and equity respectively for each educational system and each school seems imperative (Doyle, 2008). Increasing stakeholders' awareness of the importance of reducing the SES gap in student achievement could also be raised, especially in those countries and schools where final student learning results (after controlling for HISEI) could be considered satisfactory but where SES still plays a very important role in achieving these results. Using international studies to provide this type of feedback to policy-makers may also help them evaluate their own national reform policies on promoting quality and equity since they could examine not only the extent to which students' mean performance has improved, but also whether the SES gap in student achievement has reduced.

\section{Quality and equity at teacher and school level: a reanalysis of national effectiveness studies}

One can claim that the secondary analyses of PISA cycles looked at the quality and equity dimensions of effectiveness by not following a value-added approach. Specifically, quality was examined by looking at the final student learning outcomes and controlling only for the effect of background factors, whereas EER reveals the importance of investigating the impact of teachers/schools/systems on student achievement gains (Creemers et al., 2010). Similarly, it is proposed here that the reduction of the impact of SES on student achievement should be considered when measuring the equity dimension. However, the choice of a different method to investigate the relationship between quality and equity in education can be attributed to the fact that PISA is a cross-sectional study. In this context, we briefly present here the main results of secondary analyses of two effectiveness studies which sought to identify the relationship between quality and equity at the teacher and/or school level. Specifically, Kyriakides, Creemers, and Charalambous (2019) reanalysed the data from two effectiveness studies which were initially conducted in order to test the validity of the dynamic model of educational effectiveness (Creemers \& Kyriakides, 2008a). Readers can find information about the methods of these two studies in two relevant papers (i.e., Kyriakides \& Creemers, 2008a, 2009) in which the impact of factors included in the dynamic model on student achievement gains is examined. However, this secondary analysis moves a step further and investigates differential teacher and school effectiveness in terms of two student background factors that are not likely to change (i.e., SES and gender). It is important to note that the two effectiveness studies collected data from two different phases of 
schooling in the two core subjects (mathematics and language). There is therefore an examination of whether four separate analyses (concerned with achievement in two different subjects and at two different phases of schooling) might generate similar results regarding the relationship between quality and equity. Specifically, Kyriakides, Creemers, and Charalambous (2019) investigate whether primary and/or pre-primary teachers and schools, which are more effective in terms of promoting student learning outcomes, tend to have a smaller SES gap and/or a smaller gender gap with respect to student achievement. In this way, we can explore the relationship between quality and equity in different phases of schooling (i.e., pre-primary and primary education) and when achievement in the two core subjects of the curriculum (i.e., mathematics and language) is taken into account. To achieve this aim, separate multilevel analyses (students within classrooms/teachers within schools) of student achievement in each subject were initially conducted. These analyses revealed that student background factors (i.e., prior achievement, SES and gender) had significant effects on student achievement in each subject. Then, random-slope multilevel models were used to search for differential effects of SES and gender at teacher and school level (see Kyriakides, Creemers, \& Charalambous, 2019). It is, however, important to note here that equity was seen not only in relation to the impact of SES on achievement, but also in relation to the impact of gender.

Similar results emerged from the four separate analyses exploring the relationship between the two dimensions of effectiveness. Specifically, none of these two effectiveness studies reveal any negative relationship between the two dimensions of effectiveness (i.e., quality and equity). Gaps in achievement based on background factors were not found to be bigger in pre-primary and primary classrooms and in schools which were more effective in terms of promoting student learning outcomes. These findings seem to provide empirical support to those who argue that promotion of equity may have a positive impact on quality (Kelly, 2012; Kyriakides, Creemers, \& Charalambous, 2018). In addition, both studies reveal that the SES gap in student achievement in the two core subjects (i.e., mathematics and language) tends to be smaller in classrooms and schools which are more effective than others in promoting student learning outcomes. Thus, these two studies seem to reveal that there is a positive relationship between the two dimensions of teacher and school effectiveness in pre-primary and primary schools in Cyprus (i.e., the country where these two studies were conducted) when SES is considered in measuring equity at classroom and school level. It should, however, be acknowledged that although the SES gap is smaller in effective classrooms and schools, this does not imply that the effect of SES on achievement disappears or even became smaller during the school year that the study was conducted.

On the other hand, these two longitudinal studies seem to reveal a different picture when equity is examined with regard to the gender gap rather than the SES gap. Neither a positive nor a negative relationship between quality and equity was identified when we searched for differential teacher and school effectiveness in terms of gender in the pre-primary and primary education of 


\section{Quality and equity in education}

Cyprus. Although both studies revealed differential teacher and school effects in terms of the impact of gender on student achievement, the gender gap was not found to be smaller in schools and/or classrooms which were more effective in terms of promoting overall student achievement gains in each subject. This implies that in investigating the relationship between quality and equity, one should make explicit which of the background factors is taken into account when measuring equity. This argument is also supported by the fact that the covariance of the residuals of the two random slopes at each level was not statistically significant at level .05. This implies that in those classrooms and schools where the SES gap with respect to achievement is smaller, the gender gap is not necessarily smaller. Therefore, these two studies seem to reveal that teachers and schools which could be considered effective when the equity dimension in terms of the SES gap is taken into account do not tend to be effective in terms of equity when the gender gap is taken into account. This finding can, however, be attributed to the national and/or local policies on promoting equity in Cyprus, which treat equity only in relation to the impact of SES rather than to the impact of any student background factor that is unlikely to change (e.g., gender, ethnicity). One could therefore argue for the importance of generating mechanisms to measure equity in a systematic way and to provide comprehensive feedback for schools and teachers to help them develop strategies and action plans that can address specific elements of equity. For example, teachers and schools which were found to be less effective when equity in terms of gender is considered but not when the SES gap is taken into account may have to develop different strategies and action plans to improve their own effectiveness status in terms of equity, rather than those which were found to be less effective in terms of equity when both SES and gender gaps were taken into account. It should finally be stressed that the findings of these two studies reveal similar patterns in terms of the relationship between quality and equity in Cypriot pre-primary and primary schools when achievement in two different subjects is considered. This implies that investigating the relationship between quality and equity might be less dependent on the learning outcome that is being considered (mathematics or language) than the background factor that is taken into account when measuring equity. The fact that similar results emerged from measuring effectiveness in terms of two different subjects (i.e., mathematics and language) and in two different phases of schooling seems to be in line with previous effectiveness studies conducted in Cyprus, which revealed that primary teachers who are effective in promoting student achievement gains in a specific subject tend also to be effective in promoting achievement in another subject (e.g., Kyriakides, 2005a; Kyriakides \& Creemers, 2008a). However, the reanalyses of these two effectiveness studies seem to reveal that there is no simple answer to the question about the relationship between the two dimensions of effectiveness. In the pre-primary and primary schools of Cyprus, the relationship between quality and equity seemed to be more dependent on the student background factor that was being considered when measuring equity and less on the learning outcome that was being taken into account. When SES 
was considered, a positive relationship between quality and equity was observed for both subjects, but this was not the case when gender was the focus.

\section{Lessons learnt from the secondary analyses of national and international studies in education}

Before we move on to presenting the results of an experimental study on promoting quality and equity, we will try to compare the findings that emerged from the two national effectiveness studies with those that arose from the secondary analyses of the PISA cycles. Both national and international studies seemed to reveal that there is no negative statistically significant relationship between the two dimensions of effectiveness at any level (i.e., teacher/school/ country level) that was examined. On the contrary, a positive relationship between quality and equity seemed to exist when equity in relation to SES was examined. In the case of the PISA studies, a consistently positive relationship was observed when the parents' occupational status was taken into account. One could therefore claim that teachers, schools and educational systems which are effective in terms of equity tend to be effective in terms of quality. One should also bear in mind that despite the differences in the two types of analyses presented in this section, a similar conclusion concerning the relationship between quality and equity could be drawn. Specifically, the national studies were able to measure quality by looking at the impact that teachers and the school have on student learning outcomes (after controlling for student background factors and especially prior achievement), whereas the PISA study is cross-sectional and is therefore not possible to identify the impact of schools and countries on student achievement gains. Moreover, the national studies collected data from two different phases of education (pre-primary and primary), whereas PISA is concerned with achievement of students in a different phase of education (i.e., secondary school). Furthermore, the learning outcomes taken into account by the national studies and PISA were not the same. Therefore, the argument that there is a positive relationship between quality and equity seems to be stronger since it is supported by the results obtained from the analysis of data from two different types of study and from studies that used different types of student learning outcome (mathematics, reading and science). It is finally important to stress that these studies were concerned with education in three different phases (i.e., pre-primary, primary and secondary). Having said that, we also acknowledge that there is a need for further research to investigate the generalisability of these findings by using multiple methods of data collection and looking at different types of learning outcome (especially since only cognitive learning outcomes were examined in the studies reported here).

It is also important to note that this relationship should not be misinterpreted. The fact that a positive relationship is reported does not mean that there is no teacher, school or country which is effective in terms of one dimension but less effective in terms of the other dimension. On the contrary, correlation coefficients reported in these studies were relatively small and might partly have 


\section{Quality and equity in education}

depended on the policies and practices that might have promoted effectiveness in terms of only one dimension. Nevertheless, these results reveal that promoting equity does not have a negative impact on quality. In addition, the results of the secondary analysis of national and international studies seem to reveal that it is possible for teachers, schools and countries to be effective in terms of both quality and equity.

At the same time, the studies reported here reveal the complexity of reporting results on equity and investigating the relationship between quality and equity (Kyriakides, Creemers, \& Charalambous, 2018). Although these studies show that a positive relationship between quality and equity seemed to exist when different learning outcomes and/or methods to measure quality were used, they also reveal different types of relationship when different indicators for measuring equity were used. The two national studies reveal no relationship between quality and equity when gender rather than SES was taken into account. This implies that we cannot take for granted that there is criterion consistency when measuring equity. Researchers and policy-makers should not only explain how equity is conceptualised and measured (see Kelly, 2012; Kyriakides, Creemers, \& Charalambous, 2018), but should also indicate the background factor considered when measuring equity. Although further research to test the generalisability of the findings of these studies is needed, the results of these national and international studies at least raise awareness of the importance of measuring equity and investigating the relationship between quality and equity in a more systematic way by taking into consideration various student background factors that are unlikely to change, rather than just a single indicator.

\section{Exploring the relationship between quality and equity in education by drawing on the results of a European experimental study}

We would like now to move on to the presentation of the results of an experimental study which was conducted in four different European countries (i.e., Cyprus, England, Greece and Ireland) in order to support primary schools in socially disadvantaged areas in their attempt to promote quality and equity in education (Kyriakides, Charalambous, Creemers, Antoniou et al., 2019). Although this study was not naturalistic in character and cannot be used for modelling effectiveness, it is in line with the main aim of this book, which is not only to raise awareness of the importance of establishing theories to explain effectiveness in terms of both dimensions (Part 1 of the book), but also to develop a theory-driven and evidence-based improvement approach to promoting quality and equity in education (Part 2 of the book). Given that children in socially disadvantaged areas are more likely to have lower achievement levels, the study reported here investigated the extent to which a whole-school intervention based on the DA to school improvement (Creemers \& Kyriakides, 2012) could promote both quality and equity in socially disadvantaged primary schools in four European countries (i.e., Cyprus, England, Greece and Ireland). This 
was done by investigating the extent to which schools and teachers were able to reduce the gaps in mathematical achievement among students from different socioeconomic backgrounds. At this point it should be noted that the four European countries participating in this study were chosen because the promotion of equity is considered a priority in each of these countries (see OECD, 2010a; OECD, 2012). However, there is a variation between these four countries regarding the way that educational policy is applied to schools in order to support students who come from low socioeconomic backgrounds. Therefore, this study aimed to investigate the impact of this project on quality and equity in each of these four countries in order to find out whether similar arguments about changes in the equity and quality dimension of school effectiveness in four different countries would emerge. Readers can find information about the methods of this study and the intervention on the web page of the project (www.ucy.ac.cy/promqe): in this chapter, we only refer briefly to the main findings. Specifically, it should be noted that this study revealed that by using the DA not only the quality dimension of school effectiveness, but also equity in each participating country was promoted.

Explicitly, by conducting separate multilevel analyses in each participating country, it was shown that schools which made use of the DA were more effective than the control schools when it came to promoting student achievement in mathematics. By using multilevel structural equation modelling techniques, it was found that this intervention had not only a direct, but also an indirect effect on student achievement. With regard to the impact of the project on equity, it is stressed here that at the beginning of the intervention, the effect of SES on student achievement was equally strong in both the experimental and the control groups. At the end of the intervention, the direct effect of SES on student achievement became smaller only in the schools in the experimental group. With regard to the total effect of SES on student achievement in mathematics, a difference between the two groups was also identified. It is, however, important to note that by comparing the effect of SES on initial achievement of students in the experimental group with the total impact of SES on their final achievement, one can see that it remained equally high. Nevertheless, one should not underestimate the impact of the DA on promoting equity since the total effect of SES in the control schools increased substantially in each country, and this finding is in line with the results of longitudinal studies conducted in different countries, which reveal that the total effect of SES gradually increases over time (Hansen, Rosén, \& Gustafsson, 2011; Sammons, 2008). One might then claim that the intervention had a positive effect on equity since, by comparing the impact of SES on achievement at two points in time, one can see that there was no difference before the intervention, whereas at the end of the intervention SES was found to matter less in the experimental schools than in the schools in the control group.

The results of longitudinal studies, such as the ones mentioned previously, and also of the present study that took place in schools for only one school year, demonstrating an increase in the impact of SES over time, reveal that 


\section{Quality and equity in education}

policy-makers and school stakeholders should consider as a priority the promotion of equity at school level. At the same time, these results reveal the complexity of evaluating interventions that aim to promote equity. We argue here for the importance of collecting longitudinal data in order to establish formative school evaluation mechanisms and to measure changes in the impact of background factors on student achievement over time. This suggestion seems to be in line with the claim that value-added approaches are needed when measuring the quality dimension and comparing the contribution that each teacher/school/ system may make to student achievement gains rather than comparing schools on the basis of their final student learning outcomes (Creemers et al., 2010). In the case of equity, we should also seek to identify changes over time on the impact that SES (or other background factors such as gender and ethnicity) has on achievement and compare the changes on the impact of SES (positive or negative) in individual schools with those that apply to the whole population (see Figure 1.1). In a case in which an increase in the impact of SES is observed at the country level, any school with a much smaller increase (or no increase at all) could still be considered effective in terms of equity. Thus we argue for the need to establish continuous formative evaluation mechanisms to assess student achievement gains and the impact of SES on achievement over time in order to help teachers, schools and educational systems identify changes in their effectiveness status in terms of both dimensions of educational effectiveness (quality and equity).

In Figure 1.1, we argue that both dimensions of effectiveness are based on the assumption that there is a need to measure the effectiveness status of schools over time and in relation to an overall trend that is observed in a specific setting. In regard to the quality dimension, a relation between the prior and final achievement for the whole population (e.g., a specific region/country) can be identified. One can, therefore, claim that those teachers/schools that help their students achieve more than expected can be considered as the most effective whereas those who can achieve less than expected can be considered as least effective. Using a similar approach, we can claim that in a specific setting (e.g., a specific country), one can observe changes in the impact of SES (or any other background factor) on student achievement over time (i.e., an increase in the effect of SES on student achievement over time is usually identified). Effective teachers/schools are, therefore, considered those where the impact of the background factor on student achievement becomes less important than what is observed in the specific country. It is for this reason that one can consider the schools of the experimental group of this project more effective than those of the control group since an increase in the effect of SES was observed in the schools of the control group but in the schools of the experimental group the impact of SES on achievement remained the same. Figure 1.1 does not only reveal the importance of considering different types of student learning outcomes (not only cognitive) when student achievement is measured but also that equity can be measured in terms of the impact on achievement of different background characteristics which are unlikely to change. It is finally stressed that Figure 1.1 
reveals the importance of conducting studies searching for the relation between the two dimensions of effectiveness. One could move a step forward and argue that further research is needed to develop theoretical models addressing both dimensions of effectiveness and using these models to establish strategies for promoting not only quality, but also equity in education over a longer period of time rather than a single school year, as is the case of the project reported here. In this context, both the short- and long- term effects of teachers/schools/ systems in promoting quality and equity in education should be examined.

\section{Aim and structure of the book}

In this chapter, we argue for the importance of promoting quality and equity in education. The use of two different dimensions for measuring effectiveness is proposed. In the last part of this chapter, we also argue for the importance of conducting studies to investigate the relationship between the two dimensions of effectiveness, and we present the results from different types of study, which reveal that promoting equity has no negative effect on promoting quality. Thus the principal objective of this book is to make a contribution to knowledge and theory-building in research on promoting quality and equity in education. The book draws attention to the importance not only of developing and testing theories of educational effectiveness, but also of using these theories for improvement purposes. For this reason, we refer to recent theoretical developments in the field of educational effectiveness and propose an improved version of the dynamic theory that takes into account findings of studies that have tested its validity. We also discuss the extent to which links between EER and research on school improvement can be established. Thus the rationale and the main features of the DA to teacher and school improvement are presented. We then refer to studies testing the impact of this approach to promoting quality and equity and discuss the importance of seeking to identify the circumstances in which the DA can be used for improvement purposes. In the last part of the book, we propose a broadening of the agenda of research on educational effectiveness and improvement and claim that research on developing and testing theories of educational effectiveness can contribute significantly to establishing an effective approach to teacher and school improvement that can make a major contribution to promoting quality and equity in education.

More specifically, the book is split into three parts. The first part refers to theories of educational effectiveness, which have been developed over the last four decades. During that time, researchers moved from searching for the impact of isolated factors operating at a single level to the development of integrated models which refer to factors operating at different levels, which are associated with different theoretical perspectives of effectiveness. In Chapter 2, we also refer to studies that test the validity of the integrated models and which reveal their strengths and limitations. It is also argued that the dynamic nature of educational effectiveness should be considered in developing the theoretical framework of EER. In this respect, the rationale and major assumptions of this 
theory are presented in Chapter 3. Effectiveness factors operating at different levels and their measurement dimensions are also outlined and the concept of grouping of factors is introduced. In the final chapter of this part, empirical studies conducted to test the validity of this theory are presented. These empirical studies as well as relevant meta-analyses provide support for the importance of specific factors included in the dynamic theory of educational effectiveness and their measurement dimensions. Empirical studies also reveal relationships among factors operating at the classroom level, which help us define specific stages of effective teaching. On the other hand, empirical studies reveal possibilities for establishing a more parsimonious model. Thus an improved version of the dynamic model of educational effectiveness is presented in the last part of the book.

The second part of this book provides an overview of research on school improvement and argues for the importance of using an evidence-based and theory-driven approach. More specifically, Chapter 5 presents a review of research on school improvement and also the main characteristics of different approaches to school improvement. To avoid a representation of improvement in effectiveness that is restricted in scope, a brief review of the literature on improvement which is concerned with other theoretical orientations within education that examine the process of change is also provided. It is then argued that the link between EER and school improvement is problematic. The reasons for this disappointing situation are analysed in the hope of creating more productive cooperation between EER and research on teacher and school improvement. After a careful analysis of the failure to link EER and research on teacher and school improvement effectively, we argue for the establishment of strategies for school improvement which place emphasis on the evidence stemming from theory and research. In this way, a theory-driven and evidence-based approach to teacher and school improvement is promoted. Thus, in Chapter 6 we refer to the DA to teacher and school improvement, which makes use of theory and research findings from effectiveness studies, and the rationale and main features of this approach are therefore presented. In this chapter, we also give examples of a teacher and a school-based intervention which took place in different countries to help readers understand how this DA was put into practice in order to improve the quality of teaching and the school learning environment. In the final chapter of this part, we refer to studies that have investigated the added value of using this DA to promoting quality and equity. By presenting these studies, the readers are provided with concrete examples of school improvement strategies and action plans, which were developed by making use of this approach. Chapter 7 also demonstrates how this approach was put into practice in different contexts, and, more importantly, discusses possibilities for establishing stronger links between theories of educational effectiveness and research on teacher and school improvement in order to promote not only quality, but also equity in education.

The last part of this book is an attempt to propose an agenda for establishing stronger links between research on modelling educational effectiveness and that on improving quality and equity in education. Specifically, Chapter 8 presents 
an improved version of the dynamic model that also takes into account the need for schools not only to find ways to improve student learning outcomes, but also to reduce differences in initial achievement of students from different socioeconomic backgrounds. In this chapter, we also explore ways of expanding the DA by considering the findings of a synthesis of improvement studies presented in Part 2, which reveal the importance of looking at the conditions under which the DA can be used to promote quality and equity in education. In the final chapter of this book, we draw implications for research, policy and practice. More specifically, we refer to areas that need further investigation in order to test the improved version of the dynamic theory of effectiveness and to search for ways to use this theory for improvement purposes. We also argue for the importance of investigating the impact of different improvement approaches on student learning outcomes and exploring the conditions under which each approach can be used to promote quality and equity. With regard to implications for policy and practice, we stress the importance of using theories of educational effectiveness when establishing conditions, structures and support mechanisms for the effective use of the DA to teacher and school improvement. We finally argue for the establishment of a monitoring system that is able not only to evaluate the impact of the improvement strategies and action plans, but also to identify actions that could be taken in order to maximise the effect of the DA to teacher and school improvement in specific school settings in terms of promoting both quality and equity in education. 


\section{References}

Alegre, M. À., \& Ferrer, G. (2010). School regimes and education equity: Some insights based on PISA 2006. British Educational Research Journal, 36(3), 433-461. https://doi.org/10.1080/01411920902989193

Allport, G. (1937). Personality: A psychological interpretation. New York: Holt. https://doi.org/10.1177/0002716238198001142

Anderson, L. W. (1995). Time allocated and instructional. In L. W. Anderson (Ed.), International encyclopaedia of teaching and teacher education (pp 204-207). Oxford: Elsevier.

Andrich, D. (1988). A general form of Rasch's Extended Logistic Model for partial credit scoring. Applied Measurement in Education, 1(4), 363-378. https://doi. org/10.1207/s15324818ame0104_7

Antoniou, P. (2013). A longitudinal study investigating relations between stages of effective teaching, teaching experience, and teacher professional development approaches. Journal of Classroom Interaction, 48(2), 25-40.

Antoniou, P., \& Griaznova, J. A. (2018). Promoting quality and equity: An exploratory case study of a primary school in England exploring barriers and facilitators in implementing the dynamic approach to school improvement. Studies in Educational Evaluation, 57, 53-62. https://doi.org/10.1016/j.stueduc.2017.03.002

Antoniou, P., \& Kyriakides, L. (2011). The impact of a dynamic approach to professional development on teacher instruction and student learning: Results from an experimental study. School Effectiveness and School Improvement, 22(3), 291-311. https://doi.org/10.1080/09243453.2011.577078

Antoniou, P., \& Kyriakides, L. (2013). A dynamic integrated approach to teacher professional development: Impact and sustainability of the effects on improving teacher behavior and student outcomes. Teaching and Teacher Education, 29(1), 1-12. https://doi.org/10.1016/j.tate.2012.08.001

Arora, C. M. J. (1996). Defining bullying: Towards a clearer general understanding and more effective intervention strategies. School Psychology International, 17(4), 317-329. https://doi.org/10.1177/0143034396174002

Atkinson, B. A. (2015). Inequality: What can be done? Cambridge, MA: Harvard University Press.

Azigwe, J. B., Kyriakides, L., Panayiotou, A., \& Creemers, B. P. M. (2016). The impact of effective teaching characteristics in promoting student achievement in Ghana. International Journal of Educational Development, 51, 51-61. https://doi. org/10.1016/j.ijedudev.2016.07.004

Azkiyah, S. N., Doolaard, S., Creemers, B. P. M., \& Van Der Werf, M. P. C. (2014). The effects of two intervention programs on teaching quality and student achievement. Journal of Classroom Interaction, 49(1), 4-11.

Baldry, A. C., \& Farrington, D. P. (2007). Effectiveness of programs to prevent school bullying. Victims and Offenders, 2(2), 183-204. https://doi.org/10.1080/ 15564880701263155

Ball, D. L., \& Forzani, F. M. (2011). Building a common core for learning to teach, and connecting professional learning to practice. American Educator, 35(2), 17-21, 38-39.

Bamburg, J. D. (1994). Raising expectations to improve student learning. Oak Brook, IL: North Central Regional Educational Lab. 
Bandura, A. (1989). Regulation of cognitive processes through perceived self-efficacy. Developmental Psychology, 25(5), 729-735. https://doi.org/10.1037/00121649.25.5.729

Bandura, A. (1997). Self-efficacy: The exercise of control. New York: W. H. Freeman and Company.

Baumert, J., \& Demmrich, A. (2001). Test motivation in the assessment of student skills: The effects of incentives on motivation and performance. European Journal of Psychology of Education, 16(3), 441-462. https://doi.org/10.1007/ BF03173192

Beaton, A. E., Mullis, I. V. S., Martin, M. O., Gonzalez, E. J., Kelly, D. L., \& Smith, T. A. (1996). Mathematics achievement in the middle school years. IEA's Third International Mathematics and Science Study (TIMSS). Chestnut Hill, MA: Boston College, TIMSS International Study Center.

Becker, B. J., Kennedy, M. M., \& Hundersmarck, S. (2003, April). Hypothesis about 'quality': A decade of debates. Paper presented at the annual meeting of the American Educational Research Association, Chicago, IL.

Beerens, D. R. (2000). Evaluating teaching for professional growth. Thousands Oaks, CA: Corwin Press.

Bell, L., \& Stevenson, H. (2006). Education policy: Process, themes and impact. Leadershipfor learning. London: Routledge. https://doi.org/10.4324/9780203088579

Berliner, D. (1994). Expertise: The wonder of exemplary performances. In J. Mangieri \& C. Block (Eds.), Creating powerful thinking in teachers and students: Diverse perspectives (pp. 161-186). Fort Worth, TX: Harcourt Brace College.

Bernhardt, V. L. (2004). Data analysis for continuous school improvement (2nd ed.). Larchmont, NY: Eye on Education. https://doi.org/10.4324/9781315101026

Bierman, K., Nix, R. L., Greenberg, M. T., Blair, C., \& Domitrovich, C. (2008). Executive functions and school readiness intervention: Impact, moderation, and mediation in Head Start REDI program. Development and Psychopathology, 20(3), 821-843. https://doi.org/10.1017/S0954579408000394

Black, P., \& Wiliam, D. (1998). Inside the black box: Raising standards through classroom assessment. London: King's College London School of Education. https:// doi.org/10.1177/003172171009200119

Bond, T. G., \& Fox, C. M. (2001). Applying the Rasch model: Fundamental measurement in the human Sciences. Mahwah, NJ: Lawrence Erlbaum Associates.

Borko, H. (2004). Professional development and teacher learning: Mapping the terrain. Educational Researcher, 33(8), 3-15. https://doi.org/10.3102/ 0013189X033008003

Borko, H., Jacobs, J., \& Koellner, K. (2010). Contemporary approaches to teacher professional development: Processes and content. In P. Peterson, E. Baker, \& B. McGaw (Eds.), International encyclopedia of education (Vol. 7, pp. 548-556). Oxford: Elsevier. https://doi.org/10.1016/B978-0-08-044894-7.00654-0

Bosker, R. J., \& Scheerens, J. (1994). Alternative models of school effectiveness put to test. International Journal of Educational Research, 21(2), 159-180. https:// doi.org/10.1016/0883-0355(94)90030-2

Boud, D., Cohen, R., \& Walker, D. (1993). Using experience for learning. Buckingham, UK: SRHE/Open University Press.

Britzman, D. P. (1991). Practice makes practice: A critical study of learning to teach. Albany, NY: State University of New York Press. https://doi.org/10.1177/ 027046769301300158 
Brookhart, S. M. (1997). Effects of the classroom assessment environment on mathematics and science achievement. Journal of Educational Research, 90(6), 323-330. https://doi.org/10.1080/00220671.1997.10544590

Brookover, W. B., Beady, C., Flood, P., Schweitzer, J., \& Wisenbaker, J. (1979). School systems and student achievement: Schools make a difference. New York: Praeger.

Brophy, J., \& Good, T. L. (1986). Teacher behaviour and student achievement. In M. C. Wittrock (Ed.), Handbook of research on teaching (3rd ed., pp. 328-375). New York: MacMillan.

Brown, B. W., \& Saks, D. H. (1986). Measuring the effects of instructional time on student learning: Evidence from the beginning teacher evaluation study. American Journal of Education, 94(4), 480-500. https://doi.org/10.1086/443863

Bruhwiler, C., \& Blatchford, P. (2011). Effects of class size and adaptive teaching competency on classroom processes and academic outcome. Learning and Instruction, 21(1), 95-108. https://doi.org/10.1016/j.learninstruc.2009.11.004

Brundrett, M., \& Rhodes, C. (2010). Leadership for quality and accountability in education. New York: Routledge.

Buczynski, S., \& Hansen, C. B. (2010). Impact of professional development on teacher practice: Uncovering connections. Teaching and Teacher Education, 26(3), 599-607. https://doi.org/10.1016/j.tate.2009.09.006

Burry, J., \& Shaw, D. (1988). Teachers and administrators differ in assessing teacher effectiveness. Journal of Personnel Evaluation in Education, 2(1), 33-41. https:// doi.org/10.1007/BF00124964

Busato, V., Prins, F., Elshout, J., \& Hamaker, C. (1999). The relationship between learning styles, the Big Five personality traits and achievement motivation in higher education. Personality and Individual Differences, 26(1), 129-140. https://doi. org/10.1016/S0191-8869(98)00112-3

Byrne, B. (1992). Bullies and victims in a school setting with reference to some Dublin schools. Dublin: University College. https://doi.org/10.1080/03033910.1994.1 0558031

Calderhead, J., \& Shorrock, S. B. (1997). Understanding teacher education. London: Falmer Press. https://doi.org/10.4324/9780203209332

Caldwell, B., \& Spinks, J. (1988). The self managing school. Lewes: Falmer Press.

Campbell, D. T., \& Fiske, D. W. (1959). Convergent and discriminant validation by the multitrait-multimethod matrix. Psychological Bulletin, 56(2), 81-105. https:// doi.org/10.1037/h0046016

Campbell, R. J. (1985). Developing the primary school curriculum. London: Cassell. Campbell, R. J., Kyriakides, L., Muijs, R. D., \& Robinson, W. (2003). Differential teacher effectiveness: Towards a model for research and teacher appraisal. Oxford Review of Education, 29(3), 347-362. https://doi.org/10.1080/ 03054980307440

Campbell, R. J., Kyriakides, L., Muijs, R. D., \& Robinson, W. (2004). Assessing teacher effectiveness: A differentiated model. London: RoutledgeFalmer.

Caro, D. H., \& Lenkeit, J. (2012). An analytical approach to study educational inequalities: 10 hypothesis tests in PIRLS 2006. International Journal of Research \& Method in Education, 35(1), 3-30. https://doi.org/10.1080/17437 27X.2012.666718

Carroll, J. B. (1963). A model of school learning. Teachers College Record, 64(8), $723-733$. 
Carver, F. D., \& Sergiovanni, T. J. (1969). Organizations and human behavior: Focus on schools. New York: McGraw-Hill.

Chandler, P., Robinson, W. P., \& Noyes, P. (1991). Is a proactive student teacher a better student teacher? Research in Education, 45(1), 41-52. https://doi. org/10.1177/003452379104500104

Chapman, C. J. (2004). Leadership for improvement in urban and challenging contexts. London Review of Education, 2(2), 95-108. https://doi.org/10.1080/ 1474846042000229449

Chapman, C. J. (2005). Improving schools through external intervention. London: Continuum.

Chapman, C., \& Fullan, M. (2007). Collaboration and partnership for equitable improvement: Towards a networked learning system? School Leadership and Management, 27(3), 207-213. https://doi.org/10.1080/13632430701379354

Chapman, C., \& Hadfield, M. (2010). Realising the potential of school-based networks. Educational Research, 52(3), 309-323. https://doi.org/10.1080/001318 81.2010 .504066

Chapman, C., \& Harris, A. (2004). Improving schools in difficult and challenging contexts: Strategies for improvement. Educational Research, 46(3), 219-228. https://doi.org/10.1080/0013188042000277296

Chapman, C., Muijs, D., Reynolds, D., Sammons, P., \& Teddlie, C. (2016). The Routledge international handbook of educational effectiveness and improvement. London: Routledge. https://doi.org/10.4324/9781315679488

Charalambous, E., Kyriakides, L., \& Creemers, B. P. M. (2018). Promoting quality and equity in socially disadvantaged schools: A group-randomisation study. Studies in Educational Evaluation, 57, 42-52. https://doi.org/10.1016/j.stueduc.2016.06. 001

Charalambous, C. Y., Kyriakides, E., Tsangaridou, N., \& Kyriakides, L. (2017). Exploring the reliability of generic and content-specific instructional aspects in physical education lessons. School Effectiveness and School Improvement, 28(4), 555-577. https://doi.org/10.1080/09243453.2017.1311929

Chen, D. T., Wang, L. Y., \& Neo, W. L. (2015). School-based curriculum development towards a culture of learning: Nonlinearity in practice. British Journal of Educational Studies, 63(2), 213-228. https://doi.org/10.1080/00071005.2015 .1034236

Cheng, Y. C. (1993). Profiles of organizational culture and effective schools. School Effectiveness and School Improvement, 4(2), 85-110. https://doi.org/10.1080/ 0924345930040201

Cheng, Y. C. (1996). School effectiveness and school-bases management: A mechanism for development. London: The Falmer Press.

Cheng, Y. C. (2005). Economic considerations in education reforms and policymaking. In New paradigm for re-engineering education: Globalization, localization and individualization (pp. 117-145). Dordrecht: Springer. https://doi. org/10.1007/1-4020-3620-5_6

Choi, J. I., \& Hannafin, M. (1995). Situated cognition and learning environments: Roles, structures, and implications for design. Educational Technology Research and Development, 43(2), 53-69. https://doi.org/10.1007/BF02300472

Christoforidou, M. (2013). Teacher professional development in classroom assessment: Using the dynamic model of educational effectiveness to improve assessment practice. Doctoral thesis. Nicosia, Cyprus: University of Cyprus, Department of Education. 
Christoforidou, M., Kyriakides, L., Antoniou, P., \& Creemers, B. P. M. (2014). Searching for stages of teacher skills in assessment. Studies in Educational Evaluation, 40, 1-11. https://doi.org/10.1016/j.stueduc.2013.11.006

Christoforidou, M., \& Xirafidou, E. (2014). Using the dynamic model to identify stages of teacher skills in assessment. Journal of Classroom Interaction, 49(1), 12-25. https://doi.org/10.13140/2.1.4511.2969

Chudgar, A, \& Luschei, T. F. (2009). National income, income inequality, and the importance of schools: A hierarchical cross-national comparison. American Educational Research Journal, 46(3), 626-658. https://doi.org/10.3102/ 0002831209340043

Clark, R. E., \& Salomon, G. (1986). Media in teaching. In M. Wittrock (Ed.), Handbook of research on teaching (3rd ed., pp. 464-478). New York: Macmillan.

Clements, D. H., Sarama, J., Wolfe, C. B., \& Spitler, M. E. (2015). Sustainability of a scale-up intervention in early mathematics: A longitudinal evaluation of implementation fidelity. Early Education and Development, 26(3), 427-449. https:// doi.org/10.1080/10409289.2015.968242

Cochran-Smith, M., \& Zeichner, M. K. (2005). Studying teacher education: The report of the AERA Panel on Research and Teacher Education. Routledge for the AERA Panel on Research and Teacher Education.

Coffey, J. H., \& Horner, R. H. (2012). The sustainability of schoolwide positive behavior interventions and supports. Exceptional Children, 78(4), 407-422. https://doi.org/10.1177/001440291207800402

Cohen, D. K., \& Hill, H. C. (2001). Learning policy. New Haven, CT: Yale University Press.

Coleman, J. S., Campbell, E. Q., Hobson, C. F., McPartland, J., Mood, A. M., Weinfeld, F. D., \& York, R. L. (1966). Equality of educational opportunity. Washington, DC: US Government Printing Office.

Conway, J. A. (1984). The myth, mystery, and mastery of participative decision making in education. Educational Administration Quarterly, 20(3), 11-40. https:// doi.org/10.1177/0013161X84020003003

Corkindale, J., \& Trorey, G. (2002). Career dynamics in further and higher education. In G. Trorey \& C. Cullingford (Eds.), Professional development and institutional needs (pp. 79-101). Aldershot, UK: Ashgate Publishing.

Cornford, I. R. (2002). Reflective teaching: Empirical research findings and some implications for teacher education. Journal of Vocational Education \& Training, 54(2), 219-236. https://doi.org/10.1080/13636820200200196

Cousins, J. B., \& Earl, L. M. (1992). The case for participatory evaluation. Educational Evaluation and Policy Analysis, 14(4), 397-418. https://doi. org/10.3102/01623737014004397

Creemers, B. P. M. (1994). The effective classroom. London: Cassell.

Creemers, B. P. M. (2002). From school effectiveness and school improvement to effective school improvement: Background, theoretical analysis and outline of the empirical study. Educational Research and Evaluation, 8(4), 343-362. https:// doi.org/10.1076/edre.8.4.343.8814

Creemers, B. P. M., \& Kyriakides, L. (2005). Establishing links between Educational Effectiveness Research and improvement practices through the development of a dynamic model of educational effectiveness. Paper presented at the 86th Annual Meeting of the American Educational Research Association, Montreal, Quebec, Canada. 
Creemers, B. P. M., \& Kyriakides, L. (2006). Critical analysis of the current approaches to modelling educational effectiveness: The importance of establishing a dynamic model. School Effectiveness and School Improvement, 17(3), 347-366. https://doi. org/10.1080/09243450600697242

Creemers, B. P. M., \& Kyriakides, L. (2008a). The dynamics of educational effectiveness: A contribution to policy, practice and theory in contemporary schools. London and New York: Routledge.

Creemers, B. P. M., \& Kyriakides, L. (2008b). A theoretical based approach to educational improvement: Establishing links between educational effectiveness research and school improvement. In W. Bos, H. G. Holtappels, H. Pfeiffer, \& H. Rolf (Eds.), Yearbook on school improvement (pp. 41-61). Weinhem/Munchen, Germany: Juventa Verlag.

Creemers, B. P. M., \& Kyriakides, L. (2009). Situational effects of the school factors included in the dynamic model of educational effectiveness. South African Journal of Education, 29(3), 293-315. http://doi.org/10.15700/saje.v29n3a270

Creemers, B. P. M., \& Kyriakides, L. (2010a). Explaining stability and changes in school effectiveness by looking at changes in the functioning of school factors. School Effectiveness and School Improvement, 21(4), 409-427. http://doi.org/10. 1080/09243453.2010.512795

Creemers, B. P. M., \& Kyriakides, L. (2010b). School factors explaining achievement on cognitive and affective outcomes: Establishing a dynamic model of educational effectiveness. Scandinavian Journal of Educational Research, 54(1), 263-294. http://doi.org/10.1080/00313831003764529

Creemers, B. P. M., \& Kyriakides, L. (2012). Improving quality in education: Dynamic approaches to school improvement. London: Routledge. https://doi.org/10.1080/ 07294360.2012 .716939

Creemers, B. P. M., \& Kyriakides, L. (2013). Using the dynamic model to identify stages of effective teaching: An introduction to the special issue. Journal of Classroom Interaction, 48(2), 4-9.

Creemers, B. P. M., \& Kyriakides, L. (2015). Developing, testing and using theoretical models of educational effectiveness for promoting quality in education. School Effectiveness and School Improvement, 26(1), 102-119. http://doi.org/ $10.1080 / 09243453.2013 .869233$

Creemers, B. P. M., Kyriakides, L., \& Antoniou, P. (2013a). Teacher professional development for improving quality in teaching. Dordrecht, the Netherlands: Springer.

Creemers, B. P. M., Kyriakides, L., \& Antoniou, P. (2013b). A dynamic approach to school improvement: Main features and impact. School Leadership and Management, 33(2), 114-132. https://doi.org/10.1080/13632434.2013.773883

Creemers, B. P. M., Kyriakides, L., \& Sammons, P. (2010). Methodological advances in educational effectiveness research. London and New York: Routledge.

Creemers, B. P. M., \& Reezigt, G. J. (1996). School level conditions affecting the effectiveness of instruction. School Effectiveness and School Improvement, 7(3), 197228. https://doi.org/10.1080/0924345960070301

Creemers, B. P. M., \& Reezigt, G. J. (1997). School effectiveness and school improvement: Sustaining links. School Effectiveness and School Improvement, 8(4), 396-429. https://doi.org/10.1080/0924345970080402

Creemers, B. P. M., \& Reezigt, G. J. (2005). Linking school effectiveness and school improvement: The background and outline of the project. School Effectiveness and School Improvement, 16(4), 359-371. https://doi.org/10.1080/ 09243450500234484 
Creemers, B. P. M., Stoll, L., \& Reezigt, G. (2007). Effective school improvement ingredients for success: The results of an international comparative study of best practice case studies. In T. Townsend (Ed.), International handbook of school effectiveness and improvement (pp. 825-838). Dordrecht: Springer. https://doi. org/10.1007/978-1-4020-5747-2_44

Cronbach, L. J. (1990). Essentials of psychological testing (3rd ed.). New York: Harper \& Row.

Cunha, F., \& Heckman, J. J. (2009). The economics and psychology of inequality and human development. Journal of the European Economic Association, 7(2-3), 320-364. https://doi.org/10.1162/JEEA.2009.7.2-3.320

Dall'Alba, G., \& Sandberg, J. (2006). Unveiling professional development: A critical review of stage models. Review of Educational Research, 76(3), 383-412. https:// doi.org/10.3102/00346543076003383

Danielson, C., \& McGreal, T. L. (2000). Teacher evaluation to enhance professional practice. Alexandria, VA: Association for Supervision and Curriculum Development.

Darling-Hammond, L. (2000). Teacher quality and student achievement: A review of state policy evidence. Education Policy Analysis Archives, 8(1). Retrieved from http://epaa.asu.edu/epaa/v8nl/

Darling-Hammond, L., \& McLaughlin, M. W. (1995). Policies that support professional development in an era of reform. Phi Delta Kappan, 76(8), 597-604. https://doi.org/10.1177/003172171109200622

Datnow, A., Borman, G., \& Stringfield, S. (2000). School reform through a highly specified curriculum: Implementation and effects of the core knowledge sequence. The Elementary School Journal, 101(2), 167-191. https://doi.org/10.1086/ 499663

Datnow, A., Borman, G., Stringfield, S., Overman, L. T., \& Castellano, M. (2003). Comprehensive school reform in culturally and linguistically diverse contexts: Implementation and outcomes from a four-year study. Educational Evaluation and Policy Analysis, 25(2), 143-170. https://doi.org/10.3102/01623737025002143

Debus, G., \& Schroiff, H. W. (1986). The psychology of work and organization: Current trends and issues. Selected and Edited Proceedings of the West European Conference on the Psychology of Work and Organization, Aachen, F.R.G., North Holland, Amsterdam, the Netherlands, 1-3 April 1985.

De Corte, E. (2000). Marrying theory building and the improvement of school practice: A permanent challenge for instructional psychology. Learning and Instruction, 10(3), 249-266. https://doi.org/10.1016/S0959-4752(99)00029-8

de Jong, R., Westerhof, K. J., \& Kruiter, J. H. (2004). Empirical evidence of a comprehensive model of school effectiveness: A multilevel study in mathematics in the lst year of junior general education in the Netherlands. School Effectiveness and School Improvement, 15(1), 3-31. https://doi.org/10.1076/sesi.15.1.3.27490 Demetriou, D., \& Kyriakides, L. (2012). The impact of school self-evaluation upon student achievement: A group randomization study. Oxford Review of Education, 38(2), 149-170. https://doi.org/10.1080/03054985.2012.666032

den Brok, P., van Tartwijk, J., Wubbels, T., \& Veldman, I. (2010). The differential effect of the teacher-student interpersonal relationship on student outcomes for students with different ethnic backgrounds. British Journal of Educational Psychology, 80(2), 199-221. https://doi.org/10.1348/000709909X465632 
Desimone, L. M. (2009). Improving impact studies of teacher's professional development: Toward better conceptualizations and measures. Educational Researcher, 38(3), 181-199. https://doi.org/10.3102/0013189X08331140

Devine, D., \& McGillicuddy, D. (2016). Positioning pedagogy-A matter of children's rights? Oxford Review of Education, 42(4), 424-443. https://doi.org/ 10.1080/03054985.2016.1197111

Dimosthenous, A., Kyriakides, L., \& Panayiotou, A. (2020). Short- and long-term effects of the home learning environment and teachers on student achievement in mathematics: A longitudinal study. School Effectiveness and School Improvement, 31(1), 50-79. https://doi.org/10.1080/09243453.2019.1642212

Dinham, S., Brennan, K., Collier, J., Deece, A., \& Mulford, D. (2000). The secondary head of department: Key link in the quality teaching and learning chain. Carlton, Victoria: Australian College of Education.

Domitrovich, C. E., Gest, S. D., Gill, S., Bierman, K. L., Welsh, J. A., \& Jones, D. J. (2009). Fostering high quality teaching with an enriched curriculum and professional development: Head Start REDI. American Educational Research Journal, 46(2), 567-597. https://doi.org/10.3102/0002831208328089

Dowson, M., \& McInerney, D. M. (2003). What do students say about motivational goals? Towards a more complex and dynamic perspective on student motivation. Contemporary Educational Psychology, 28(1), 91-113. https://doi.org/10.1016/ S0361-476X(02)00010-3

Doyle, A. (2008). Educational performance or educational inequality: What can we learn from PISA about France and England? Compare: A Journal of Comparative and International Education, 38(2), 205-217. https://doi.org/10.1080/ 03057920701542057

Doyle, W. (1986). Classroom organization and management. In M. C. Wittrock (Ed.), Handbook of research on teaching (3rd ed., pp. 392-431). New York: Macmillan. https://doi.org/10.1080/03057920701542057

Dreyfus, H. L., \& Dreyfus, S. E. (1986). Mind over machine: The power of human intuition and expertise in the era of the computer. New York: Free Press.

Driessen, G. W. J. M., \& Mulder, L. W. J. (1999). The enhancement of educational opportunities of disadvantaged children. In R. J. Bosker, B. P. M. Creemers, \& S. Stringfield (Eds.), Enhancing educational excellence, equity and efficiency: Evidence from evaluations of systems and schools in change (pp. 37-64). Dordrecht: Kluwer Academic Publishers.

Driessen, G., \& Sleegers, P. (2000). Consistency of teaching approach and student achievement: An empirical test. School Effectiveness and School Improvement, 11(1), 57-79.

Duckworth, K. (1983). Specifying determinants of teacher and principal work. Eugene, OR: Center for Educational Policy and Management, University of Oregon.

Duke, D. L., Showers, B. K., \& Imber, M. (1981). Studying shared decision making in schools. In S. B. Bacharach (Ed.), Organizational behavior in schools and school districts (pp. 313-351). New York: Praeger.

Dumay, X., Coe, R., \& Anumendem, D. N. (2014). Stability over time of different methods of estimating school performance. School Effectiveness and School Improvement, 25(1), 64-82. https://doi.org/10.1080/09243453.2012.759599

Eberts, R. W., \& Stone, J. A. (1988). Student achievement in public schools: Do principals make a difference? Economics Education Review, 7(3), 291-299. https:// doi.org/10.1016/0272-7757(88)90002-7 
Edmonds, R. R. (1979). Effective schools for the urban poor. Educational Leadership, $37(1), 15-24$.

Elboj, C., \& Niemelä, R. (2010). Sub-communities of mutual learners in the classroom: The case of interactive groups. Revista de Psicodidactica, 15(2), 177-189.

Ellett, C. D., \& Walberg, H. J. (1979). Principal competency, environment and outcomes. In H. J. Walberg (Ed.), Educational environment and effects (pp. 140167). Berkeley, CA: McCutchan.

Elliot, B., \& Calderhead, J. (1995). Mentoring for teacher development: Possibilities and caveats. In T. Kerry \& A. Shelton-Mayes (Eds.), Issues in mentoring (pp. 35-55). London: Routledge.

Elliot, J. (1987). Educational theory, practical philosophy and action research. British Journal of Educational Studies, 25(2), 149-170. https://doi.org/10.1080/0007 1005.1987.9973758

Elliot, J. (2002, August). Action research as the basis of a new professionalism for teachers in an age of globalisation. Paper presented at a Conference to Celebrate the Centenary Year of Beijing Normal University, Beijing, China.

Emmer, E. T., \& Stough, L. M. (2001). Classroom management: A critical part of educational psychology, with implications for teacher education. Educational Psychologist, 36(2), 103-112. https://doi.org/10.1207/S15326985EP3602_5

Espalage, D. L., \& Swearer, S. M. (2004). Bullying in American schools: $\bar{A}$ socialecological perspective on prevention and intervention. Mahwah, NJ: Erlbaum.

Fairman, S. R., \& Quinn, R. E. (1985). Effectiveness: The perspective from the organisation theory. Review of Higher Education, 9, 83-100. https://doi. org/10.1353/rhe.1985.0006

Fan, X., \& Chen, M. (2001). Parental involvement and students' academic achievement: A meta-analysis. Educational Psychology Review, 13(1), 1-22. https://doi. org/10.1023/A:1009048817385

Fauth, B., Decristan, J., Rieser, S., Klieme, E., \& Büttner, G. (2014). Student ratings of teaching quality in primary school: Dimensions and prediction of student outcomes. Learning and Instruction, 29, 1-9. https://doi.org/10.1016/j. learninstruc.2013.07.001

Field, S., Kuczera, M., \& Pont, B. (2007). No more failures: Ten steps to equity in education. Paris, France: OECD. https://doi.org/10.1787/19901496

Fielding, M. (1997). Beyond school effectiveness and school improvement: Lighting the slow fuse of possibility. In J. White \& M. Barber (Eds.), Perspectives on school effectiveness and school improvement (pp. 137-160). London: Institute of Education. https://doi.org/10.1080/0958517970080102a

Firestone, W. A., \& Herriott, R. E. (1982). Prescriptions for effective elementary schools don't fit secondary schools. Educational Leadership, 40(1), 51-53.

Fishman, B., Marx, R., Best, S., \& Tal, R. (2003). Linking teacher and student learning to improve professional development in systemic reform. Teaching and Teacher Education, 19(6), 643-658. https://doi.org/10.1016/S0742-051X (03)00059-3

Fitz-Gibbon, C. T. (1996). Monitoring education: Indicators, quality and effectiveness. London: Cassell-Continuum.

Fitzpatrick, K. (1982). The effect of a secondary classroom management training program on teacher and student behavior. Paper presented at the Annual Meeting of the American Educational Research Association (AERA), New York, 3-7 April. 
Flessa, J. J. (2012). Principals as middle managers: School leadership during the implementation of primary class size reduction policy in Ontario. Leadership and Policy in Schools, 11(3), 325-343. https://doi.org/10.1080/15700763.2012.692429

Fraser, B. J. (1995). Students' perceptions of classrooms. In L. W. Anderson (Ed.), International encyclopaedia of teaching and teacher education (pp. 416-419). Oxford: Elsevier.

Fraser, B. J., Walberg, H. J., Welch, W. W., \& Hattie, J. A. (1987). Syntheses of educational productivity research. International Journal of Educational Research, $11(2), 145-252$.

Freiberg, H. J. (Ed.). (1999). School climate: Measuring improving and sustaining healthy learning environments. London: Falmer. https://doi.org/10.4324/ 9780203983980

Frempong, G., Reddy, V., \& Kanjee, A. (2011). Exploring equity and quality education in South Africa using multilevel models. Compare, 41(6), 819-835. https:// doi.org/10.1080/03057925.2011.607488

Fullan, M. (1992). Successful school improvement. Bristol, PA: Open University Press.

Fullan, M. (2001). The new meaning of educational change (3rd ed.). New York: Teachers College.

Fullan, M., Bennett, B., \& Rolheiser-Bennett, C. (1990). Linking classroom and school improvement. Educational Leadership, 47(8), 13-19.

Gage, N. L. (1963). Paradigms for research on teaching. In N. L. Gage (Eds.), Handbook of research on teaching (pp. 94-141). Chicago, IL: Rand McNally.

Gage, N. L. (1978). The scientific basis for the art of teaching. New York: Teachers College Press. https://doi.org/10.1177/002248718003100211

Garet, M. S., Porter, A. C., Desimone, L., Birman, P. F., \& Yoon, K. S. (2001). What makes professional development effective? Results from a national sample of teachers. American Educational Research Journal, 38(4), 915-945. https://doi. org/10.3102/0002831203800491

Gijbels, D., Van de Watering, G., Dochy, F., \& Van den Bossche, P. (2006). New learning environments and constructivism: The students' perspective. Instructional Science, 34(3), 213-226. https://doi.org/10.1007/s11251-005-3347-z

Glasman, N. S., \& Biniaminov, I. (1981). Input-output analyses of schools. Review of Educational Research, 51(4), 509-539. https://doi.org/10.3102/ 00346543051004509

Goddard, Y. L., Goddard, R. D., \& Tschannen-Moran, M. (2007). A theoretical and empirical investigation of teacher collaboration for school improvement and student achievement in public elementary schools. Teachers College Record, 109(4), 877-896.

Golby, M., \& Viant, R. (2007). Means and ends in professional development. Teacher Development, 11(2), 237-243. https://doi.org/10.1080/13664530701414886

Goldstein, H. (1968). Longitudinal studies and the measurement of change. Journal of the Royal Statistical Society, 18(2), 93-117. https://doi.org/10.2307/2986775

Goldstein, H. (1997). Methods in school effectiveness research. School Effectiveness and School Improvement, 8(4), 369-395. https://doi.org/10.1080/0924345970080401

Goldstein, H. (2003). Multilevel statistical models (3rd ed.). London: Edward Arnold.

Good, T. L., \& Grouws, D. A. (1979). The Missouri mathematics effectiveness project: An experimental study in fourth-grade classrooms. Journal of Educational Psychology, 71(3), 355-362. https://doi.org/10.1037/0022-0663.71.3.355 
Goodson, J. R., McGee, G. W., \& Cashman, J. F. (1989). Situational leadership theory: A test of leadership prescriptions. Group Organization Management, 14(4), 446-461. https://doi.org/10.1177/105960118901400406

Gorard, S., Rees, G., \& Salisbury, J. (2001). Investigating the patterns of differential attainment of boys and girls at school. British Educational Research Journal, 27(2), 125-139. https://doi.org/10.1080/01411920120037090

Gray, J., Goldstein, H., \& Jesson, D. (1996). Changes and improvements in school's effectiveness: Trends over five years. Research Papers in Education, 11(1), 35-51. https://doi.org/10.1080/0267152960110104

Gray, J., Goldstein, H., \& Thomas, S. (2001). Predicting the future: The role of past performance in determining trends in institutional effectiveness at A-level. British Educational Research Journal, 27(4), 391-405. https://doi.org/10.1080/ 01411920125622

Gray, J., Hopkins, D., Reynolds, D., Wilcox, B., Farrell, S., \& Jesson, D. (1999). Improving schools: Performance and potential. Buckingham, UK: Open University Press.

Gray, J., Peng, W. J., Steward, S., \& Thomas, S. (2004). Towards a typology of genderrelated school effects: Some new perspectives on a familiar problem. Oxford Review of Education, 30(4), 529-550. https://doi.org/10.1080/0305498042000303991

Green, K. E., \& Frantom, C. G. (2002). Survey development and validation with the Rasch model. Paper presented at the International Conference on Questionnaire Development, Evaluation, and Testing, Charleston, SC, 14-17 November.

Grigorenko, E. L., \& Sternberg, R. J. (1997). Styles of thinking, abilities, and academic performance. Exceptional Children, 63(3), 295-312. https://doi. org/10.1177/001440299706300301

Grossman, P., Loeb, S., Cohen, J., \& Wyckoff, J. (2013). Measure for measure: The relationship between measures of instructional practice in middle school English language arts and teachers' value-added scores. American Journal of Education, 119(3), 445-470. https://doi.org/10.1086/669901

Gulson, K. N., \& Webb, T. (2012). Education policy racialisations: Afrocentric schools, Islamic schools, and the new enunciations of equity. Journal of Education Policy, 27(6), 697-709. https://doi.org/10.1080/02680939.2012.672655

Guskey, T. R., \& Sparks, D. (2004). Linking professional development to improvements in student learning. In E. M. Guyton \& J. R. Dangel (Eds.), Teacher education yearbook XII: Research linking teacher preparation and student performance (pp. 11-21). Dubuque, IA: Kendall/Hunt.

Gustafsson, J.-E., Nilsen, T., \& Yang Hansen, K. (2018). School characteristics moderating the relation between student socio-economic status and mathematics achievement in grade 8: Evidence from 50 countries in TIMSS 2011. Studies in Educational Evaluation, 57, 16-30. https://doi.org/10.1016/j.stueduc.2016.09.004

Hallinger, P., \& Heck, R. H. (2011a). Conceptual and methodological issues in studying school leadership effects as a reciprocal process. School Effectiveness and School Improvement, 22(2), 2011. https://doi.org/10.1080/09243453.2011.565777

Hallinger, P., \& Heck, R. H. (2011b). Exploring the journey of school improvement: Classifying and analyzing patterns of change in school improvement processes and learning outcomes. School Effectiveness and School Improvement, 22(1), 1-27. https://doi.org/10.1080/09243453.2011.565777

Han, I., \& Shin, W. S. (2016). The use of a mobile learning management system and academic achievement of online students. Computers \& Education, 102(1), 79-89. https://doi.org/10.1016/j.compedu.2016.07.003 
Hansen, K. Y., Rosén, M., \& Gustafsson, J.-E. (2011). Changes in the multi-level effects of socio-economic status on reading achievement in Sweden in 1991 and 2001. Scandinavian Journal of Educational Research, 55(2), 197-211. https:// doi.org/10.1080/00313831.2011.554700

Hanushek, E. A. (1986). The economics of schooling: Production and efficiency in public schools. Journal of Economic Literature, 24(3), 1141-1177.

Hanushek, E. A. (1989). The impact of differential expenditures on student performance. Educational Research, 66(3), 397-409. https://doi.org/10.3102/ 0013189X018004045

Hargreaves, A., \& Goodson, I. (2006). Educational change over time? The sustainability and nonsustainability of three decades of secondary school change and continuity. Educational Administration Quarterly, 42(1), 3-41. https://doi. org/10.1177/0013161X05277975

Hargreaves, D. H. (1995). School culture, school effectiveness and school improvement. School Effectiveness and School Improvement, 6(1), 23-47. https://doi. org/10.1177/0013161X05277975

Hargreaves, D. H., \& Hopkins, D. (1991). The empowered school. London: Cassell.

Harlen, W., \& James, M. (1997). Assessment and learning: Differences and relationships between formative and summative assessment. Assessment in Education, 4(3), 365-379. https://doi.org/10.1080/0969594970040304

Harskamp, E. G. (1988). Een evaluatie van rekenmethoden [An evaluation of arithmetic curricula]. Dissertation. Groningen, The Netherlands: RION.

Hattie, J. (2009). Visible learning: A synthesis of over 800 meta-analyses relating to achievement. New York: Routledge.

Heck, R. H., \& Moriyama, K. (2010). Examining relationships among elementary schools' contexts, leadership, instructional practices, and added-year outcomes: A regression discontinuity approach. School Effectiveness and School Improvement, 21(4), 377-408. https://doi.org/10.1080/09243453.2010.50009

Heckman, J. (2008). The case of investing in disadvantage young children. Big ideas for children: Investing in our nation's future. Washington, DC: First Focus.

Hedges, L. V., Laine, R. D., \& Greenwald, R. (1994). Does money matter? A metaanalysis of studies of the effects of differential school inputs on student outcomes (An exchange: Part 1). Educational Researcher, 23(3), 5-14. https://doi. org/10.3102/0013189X023003005

Hoeben, W. Th. J. G. (1994). Curriculum evaluation and educational productivity. Studies in Educational Evaluation, 20(4), 477-502. https://doi.org/10.1016/019 1-491X(94)00038-I

Hofman, R. H., Dijkstra, N. J., \& Hofman, W. H. A. (2009). School self-evaluation and student achievement. School Effectiveness and School Improvement, 20(1), 47-68. https://doi.org/10.1080/09243450802664115

Hopkins, D. (1989). Evaluating for school development. Milton Keynes: Open University Press.

Hopkins, D. (1995). Towards effective school improvement. School Effectiveness and School Improvement, 6(3), 265-274. https://doi.org/10.1080/0924345950060306

Hopkins, D. (1996). Towards a theory for school improvement. In J. Gray, D. Reynolds, C. Fitz-Gibbon, \& D. Jesson (Eds.), Merging traditions: The future of research on school effectiveness and school improvement (pp. 30-51). London: Cassell. 
Hopkins, D. (2001). School improvement for real. London: RoutldegeFalmer. https:// doi.org/10.4324/9780203165799

Hopkins, D., Ainscow, M., \& West, M. (1994). School improvement in an era of change. London: Cassell.

Houtveen, A. A. M., van de Grift, W. J. C. M., \& Creemers, B. P. M. (2004). Effective school improvement in mathematics. School Effectiveness and School Improvement, 15(3), 337-376. https://doi.org/10.1080/09243450512331383242

Hoxby, C. M. (2000). The effects of class size on student achievement: New evidence from population variation. The Quarterly Journal of Economics, 115(4), 1239-1285. https://doi.org/10.1162/003355300555060

Ioannou, C. (2017). The dynamic model of educational effectiveness tested by investigating the impact of classroom level factors on slow learners' outcomes in language: An effectiveness study on a specific student population. Unpublished doctoral dissertation. Nicosia, Cyprus: University of Cyprus, Department of Education.

Ioannou, Y., Kyriakides, L., \& Panayiotou, A. (2018). Impact and sustainability of the effect of DASI on student achievement gains in secondary education. Paper presented at the 6th Meeting of the EARLI SIGs 18 \& 23 'Towards Sustainable School Improvement through Rigorous Research'. University of Groningen, the Netherlands, 29-31 August 2018.

Isac, M. M., Maslowski, R., \& van der Werf, G. (2011). Effective civic education: An educational effectiveness model for explaining students' civic knowledge. School Effectiveness and School Improvement, 22(3), 313-333. https://doi.org/10.1080/ 09243453.2011 .571542

Jencks, C., Smith, M., Acland, H., Bane, M. J., Cohen, D., Gintis, H., . . . \& Michelson, S. (1972). Inequality: A reassessment of the effects of family and schooling in America. New York: Basic Books.

Jensen, A. R. (1969). How much can we boost IQ and scholastic achievement? Harvard Educational Review, 39(1), 1-123. https://doi.org/10.17763/ haer.39.1.13ul5956627424k7

Johnson, B. (1997). An organizational analysis of multiple perspectives of effective teaching: Implications of teacher evaluation. Journal of Personnel Evaluation in Education, 11(1), 69-87. https://doi.org/10.1023/A:1007951321381

Johnston, R., \& Usher, R. (1996). Adult learning and critical practices: Towards a re-theorisation of experience. Australian Journal of Experiential Learning, 35, 50-61.

Joyce, B., \& Showers, B. (1995). Student achievement through staff development (2nd ed.). White Plains, NY: Longman.

Joyce, B. R., Weil, M., \& Calhoun, E. (2000). Models of teaching. Boston, MA: Allyn \& Bacon.

Jürges, H., \& Schneider, K. (2004). International differences in student achievement: An economic perspective. German Economic Review, 5(3), 357-380. https://doi. org/10.1111/j.1465-6485.2004.00113.x

Katz, G. L., \& Raths, D. J. (1984). Advances in teacher education (Vol. 1). Norwood, NJ: Ablex Publishing Corporation.

Kelly, A. (2012). Measuring "equity" and "equitability" in school effectiveness research. British Educational Research Journal, 38(6), 977-1002. https://doi.org/ $10.1080 / 01411926.2011 .605874$

Kelly, A. (2015). Measuring equity in educational effectiveness research: The properties and possibilities of quantitative indicators. International Journal of Research 
and Method in Education, 38(2), 115-136. https://doi.org/10.1080/17437 27X.2014.914486

Kelly, A., \& Downey, C. (2010). Value-added measures for schools in England: Looking inside the "black box" of complex metrics. Educational Assessment, Evaluation and Accountability, 22(3), 181-198. https://doi.org/10.1007/ sl1092-010-9100-4

Ker, H. W. (2016). The impacts of student-, teacher-and school-level factors on mathematics achievement: An exploratory comparative investigation of Singaporean students and the USA students. Educational Psychology, 36(2), 254-276. https:// doi.org/10.1080/01443410.2015.1026801

Killen, R. (2007). Effective teaching strategies: Lessons from research and practice (4th ed.). Thomson: Social Science Press.

King, P. M., \& Kitchener, K. S. (1994). Developing reflective judgment: Understanding and promoting intellectual growth and critical thinking in adolescents and adults. San Francisco, CA: Jossey-Bass.

Kington, A., Sammons, P., Day, C., \& Regan, E. (2011). Stories and statistics: Describing a mixed methods study of effective classroom practice. Journal of Mixed Methods Research, 5(2), 103-125. https://doi.org/10.1177/1558689810396092

Kline, P., \& Gale, A. (1977). Extraversion, neuroticism and performance in a psychology examination. British Journal of Educational Psychology, 41, 90-94. https:// doi.org/10.1111/j.2044-8279.1971.tb00662.x

Knapp, M. S. (1997). Between systemic reforms and the mathematics and science classroom: The dynamics of innovation, implementation, and professional learning. Review of Educational Research, 67(2), 227-266. https://doi.org/10.3102/ 00346543067002227

Kochenderfer, B. J., \& Ladd, G. W. (1996). Peer victimization: Manifestations and relations to school adjustment in kindergarten. Journal of School Psychology, 34(3), 267-283. https://doi.org/10.1016/0022-4405(96)00015-5

Kokkinou, E., \& Kyriakides, L. (2018, April). Do teachers exhibit the same generic teaching skills when they teach in different classrooms? Paper presented at the annual meeting of the American Educational Research Association (AERA) 2018, New York, NY.

Kolleck, N. (2019, August). Teacher collaboration and teacher motivation in the context of school improvement. Paper presented at the Invited Symposium SIG 23 of the 18th Biennial Conference of EARLI, 'Social Interactions in School Improvement and their Relation to Instruction and Teachers' and Students' Learning', RWTH Aachen, Germany.

Kostin, M., \& Haeger, J. (2006). Coaching schools to sustain improvement. Education Digest, $71(9), 29-33$.

Koth, C. W., Bradshaw, C. P., \& Leaf, P. J. (2008). A multilevel study of predictors of student perceptions of school climate: The effect of classroom-level factors. Journal of Educational Psychology, 100(1), 96-104. https://doi.org/10.1037/ 0022-0663.100.1.96

Krueger, A. B. (2002). Understanding the magnitude and effect of class size on student achievement. In L. Mishel and R. Rothstein (Eds.), The class size debate (pp. 7-35). Washington, DC: Economic Policy Institute.

Kumar, D. D. (1991). A meta-analysis of the relationship between science instruction and student engagement Educational Review, 43(1), 49-61. https://doi. org/10.1080/0013191910430105 
Kuyper, H., Dijkstra, P., Buunk, A. P., \& van der Werf, G. P. H. (2011). Social comparisons in the classroom: An investigation of the better than average effect among secondary school children. Journal of School Psychology, 49(1), 25-53. https://doi.org/10.1016/j.jsp.2010.10.002

Kyriakides, E., Tsangaridou, N., Charalambous, C., \& Kyriakides, L. (2018). Integrating generic and content-specific teaching practices in exploring teaching quality in primary physical education. European Physical Education Review, 24(4), 418-448. https://doi.org/10.1177/1356336X16685009

Kyriakides, L. (1999). The management of curriculum improvement in Cyprus: A critique of a 'centre-periphery' model in a centralised system. In T. Townsend, P. Clarke, \& M. Ainscow (Eds.), Third millennium schools: A world of difference in school effectiveness and school improvement (pp. 107-124). Lisse: Swets and Zeitlinger.

Kyriakides, L. (2000). A developmental assessment of pupils' use of domain-specific and general strategies in problem solving. In T. Nakahara \& M. Koyama (Eds.), Proceedings of the 24th International Conference for the Psychology of Mathematics Education, 3 (pp. 207-214). Japan: Hiroshima University.

Kyriakides, L. (2004). Differential school effectiveness in relation to sex and social class: Some implications for policy evaluation. Educational Research and Evaluation, 10(2), 141-161. https://doi.org/10.1076/edre.10.2.141.27907

Kyriakides, L. (2005a). Extending the comprehensive model of educational effectiveness by an empirical investigation. School Effectiveness and School Improvement, 16(2), 103-152. https://doi.org/10.1080/09243450500113936

Kyriakides, L. (2005b). Drawing from teacher effectiveness research and research into teacher interpersonal behaviour to establish a teacher evaluation system: A study on the use of student ratings to evaluate teacher behaviour. Journal of Classroom Interaction, 40(2), 44-66.

Kyriakides, L. (2005c). Evaluating school policy on parents working with their children in class. The Journal of Educational Research, 98(5), 281-298. https://doi. org/10.3200/JOER.98.5.281-298

Kyriakides, L. (2007). Generic and differentiated models of educational effectiveness: Implications for the improvement of educational practice. In T. Townsend (Ed.), International handbook of school effectiveness and improvement (pp. 41-56). Dordrecht, the Netherlands: Springer. https://doi.org/10.1007/978-1-4020-5747-2_3

Kyriakides, L. (2008). Testing the validity of the comprehensive model of educational effectiveness: A step towards the development of a dynamic model of effectiveness. School Effectiveness and School Improvement, 19(4), 429-446. https://doi. org/10.1080/09243450802535208

Kyriakides, L., Anthimou, M., \& Panayiotou, A. (2020). Searching for the impact of teacher behavior on promoting students' cognitive and metacognitive skills. Studies in Educational Evaluation, 64. https://doi.org/10.1016/j. stueduc.2019.100810

Kyriakides, L., Archambault, I., \& Janosz, M. (2013). Searching for stages of effective teaching: A study testing the validity of the dynamic model in Canada. Journal of Classroom Interaction, 48(2), 11-24.

Kyriakides, L., \& Campbell, R. J. (2004). School self-evaluation and school improvement: A critique of values and procedures. Studies in Educational Evaluation, 30(1), 23-36. https://doi.org/10.1016/S0191-491X(04)90002-8

Kyriakides, L., Campbell, R. J., \& Gagatsis, A. (2000). The significance of the classroom effect in primary schools: An application of Creemers' comprehensive model 
of educational effectiveness. School Effectiveness and School Improvement, 11(4), 501-529. https://doi.org/10.1076/sesi.11.4.501.3560

Kyriakides, L., \& Charalambous, C. (2005). Using educational effectiveness research to design international comparative studies: Turning limitations into new perspectives. Research Papers in Education, 20(4), 391-412. https://doi.org/10.1080/ 02671520500335816

Kyriakides, L., \& Charalambous, C. Y. (2014). Educational effectiveness research and international comparative studies: Looking back and looking forward. In R. Strietholt, W. Bos, J.-E. Gustafsson, \& M. Rosén (Eds.), Educational policy evaluation through international comparative assessments (pp. 33-50). Munster \& New York: Waxmann.

Kyriakides, L., Charalambous, C., Philippou, G., \& Campbell, R. J. (2006). Illuminating reform evaluation studies through incorporating teacher effectiveness research: A case study in mathematics. School Effectiveness and School Improvement, 17(1), 3-32. https://doi.org/10.1080/09243450500404293

Kyriakides, L., \& Charalambous, E. (2020). Testing the theoretical framework of whole school interventions aiming to promote student learning outcomes: the contribution of multilevel structural equation modelling. International Journal of Research \& Method in Education. https://doi.org/10.1080/1743727X.2020.1795114

Kyriakides, L., Charalambous, E., Creemers, B. P. M., Antoniou, P., Devine, D., Papastylianou, D., \& Fahie, D. (2019). Using the dynamic approach to school improvement to promote quality and equity in education: A European study. Educational Assessment, Evaluation and Accountability, 31(1), 121-149. https:// doi.org/10.1007/s11092-018-9289-1

Kyriakides, L., Charalambous, E., Creemers, B. P. M., \& Dimosthenous, A. (2019). Improving quality and equity in schools in socially disadvantaged areas. Educational Research, 61(3), 274-301. https://doi.org/10.1080/00131881.2019.16 42121

Kyriakides, L., Christoforidou, M., Panayiotou, A., \& Creemers, B. P. M. (2017). The impact of a three-year teacher professional development course on quality of teaching: Strengths and limitations of the dynamic approach. European Journal of Teacher Education, 40(4), 465-486. https://doi.org/10.1080/02619768.2017.1 349093

Kyriakides, L., Christoforou, C., \& Charalambous, C. Y. (2013). What matters for student learning outcomes: A meta-analysis of studies exploring factors of effective teaching. Teaching and Teacher Education, 36, 143-152. https://doi.org/10.1016/j. tate.2013.07.010

Kyriakides, L., \& Creemers, B. P. M. (2008a). A longitudinal study on the stability over time of school and teacher effects on student learning outcomes. Oxford Review of Education, 34(5), 521-545. https://doi.org/10.1080/0305498 0701782064

Kyriakides, L., \& Creemers, B. P. M. (2008b). Using a multidimensional approach to measure the impact of classroom level factors upon student achievement: A study testing the validity of the dynamic model. School Effectiveness and School Improvement, 19(2), 183-205. https://doi.org/10.1080/09243450802047873

Kyriakides, L., \& Creemers, B. P. M. (2009). The effects of teacher factors on different outcomes: Two studies testing the validity of the dynamic model. Effective Education, 1(1), 61-86. https://doi.org/10.1080/19415530903043680 
Kyriakides, L., \& Creemers, B. P. M. (2011). Can schools achieve both quality and equity? Investigating the two dimensions of educational effectiveness. Journal of Education for Students Placed at Risk, 16(4), 237-254. https://doi.org/10.1080 /10824669.2011.610269

Kyriakides, L., \& Creemers, B. P. M. (2012). School policy on teaching and school learning environment: Direct and indirect effects upon student outcome measures. Educational Research and Evaluation: An International Journal on Theory and Practice, 18(5), 403-424. https://doi.org/10.1080/13803611.2012.689716

Kyriakides, L., \& Creemers, B. P. M. (2013). Characteristics of effective schools in facing and reducing bullying. School Psychology International, 34(3), 348-368. https://doi.org/10.1177/0143034312467127

Kyriakides, L., \& Creemers, B. P. M. (2018). Investigating the quality and equity dimensions of educational effectiveness. Studies in Educational Evaluation, 57, 1-5.

Kyriakides, L., Creemers, B. P. M., \& Antoniou, P. (2009). Teacher behaviour and student outcomes: Suggestions for research on teacher training and professional development. Teaching and Teacher Education, 25(1), 12-23. https://doi. org/10.1016/j.tate.2008.06.001

Kyriakides, L., Creemers, B. P. M., Antoniou, P., \& Demetriou, D. (2010). A synthesis of studies searching for school factors: Implications for theory and research. British Educational Research Journal, 36(5), 807-830. https://doi.org/ 10.1080/01411920903165603

Kyriakides, L., Creemers, B. P. M., Antoniou, P., Demetriou, D., \& Charalambous, C. (2015). The impact of school policy and stakeholders' actions on student learning: A longitudinal study. Learning and Instruction, 36, 113-124. https://doi. org/10.1016/j.learninstruc.2015.01.004

Kyriakides, L., Creemers, B. P. M., \& Charalambous, E. (2018). Equity and quality dimensions in educational effectiveness. Dordrecht, the Netherlands: Springer.

Kyriakides, L., Creemers, B. P. M., \& Charalambous, E. (2019). Searching for differential teacher and school effectiveness in terms of student socioeconomic status and gender: Implications for promoting equity. School Effectiveness and School Improvement, 30(3), 286-308. https://doi.org/10.1080/09243453.2018. 1511603

Kyriakides, L., Creemers, B. P. M., Muijs, D., Rekers-Mombarg, L., Papastylianou, D., Van Petegem, P., \& Pearson, D. (2014). Using the dynamic model of educational effectiveness to design strategies and actions to face bullying. School Effectiveness and School Improvement, 25(1), 83-104. https://doi.org/10.1080/0924345 3.2013 .771686

Kyriakides, L., Creemers, B. P. M., Papastylianou, D., \& Papadatou-Pastou, M. (2014). Improving the school learning environment to reduce bullying: An experimental study. Scandinavian Journal of Educational Research, 58(4), 453-478. https://doi.org/10.1080/00313831.2013.773556

Kyriakides, L., \& Demetriou, D. (2006). Investigating the generalisability of models of educational effectiveness: A secondary analysis of PISA study. Paper presented at the 87th Annual Meeting of the American Educational Research Association, San Francisco, CA, USA.

Kyriakides, L., Georgiou, M. P., Creemers, B. P. M., Panayiotou, A., \& Reynolds, D. (2018). The impact of national educational policies on student achievement: A European study. School Effectiveness and School Improvement, 29(2), 171-203. https://doi.org/10.1080/09243453.2017.1398761 
Kyriakides, L., Kaloyirou, C., \& Lindsay, G. (2006). An analysis of the Revised Olweus Bully/Victim Questionnaire for students using the Rasch measurement model. British Journal of Educational Psychology, 76(4), 781-801. https://doi. org/10.1348/000709905X53499

Kyriakides, L., \& Luyten, H. (2009). The contribution of schooling to the cognitive development of secondary education students in Cyprus: An application of regression-discontinuity with multiple cut-off points. School Effectiveness and School Improvement, 20(2), 167-186. https://doi.org/10.1080/09243450902883870

Kyriakides, L., Panayiotou, A., Creemers, B. P. M., \& Antoniou, P. (2013). Integrating research on teacher effectiveness with research on teacher professional development. Paper presented at the American Educational Research Association (AERA) 2013 Conference, San Francisco, CA, 27 April-1 May 2013.

Kyriakides, L., \& Tsangaridou, N. (2008). Towards the development of generic and differentiated models of educational effectiveness: A study on school and teacher effectiveness in physical education. British Educational Research Journal, 34(6), 807-838. https://doi.org/10.1080/01411920802041467

Lamb, S. (1996). Gender differences in mathematics participation in Australian schools: Some relationships with social class and school policy. British Educational Research Journal, 22(2), 223-240. https://doi.org/10.1080/0141192960220206

Lee, V. E., \& Smith, J. B. (1999). Social support and achievement for young adolescents in Chicago: The role of school academic press. American Educational Research Journal, 36(4),907-945. https://doi.org/10.3102/00028312036004907

Leithwood, K., \& Jantzi, D. (2006). Transformational school leadership for largescale reform: Effects on students, teachers and their classroom practices. School Effectiveness and School Improvement, 17(2), 201-227. https://doi. org/10.1080/09243450600565829

Lelei, H. (2019). A case study of policy and actions of Rivers State, Nigeria to improve teaching quality and the school learning environment. Unpublished doctoral dissertation. Sydney, Australia: School of Education, UNSW.

Levin, B. (2010a). The challenge of large-scale literacy improvement. School Effectiveness and School Improvement, 21(4), 359-376. https://doi.org/10.1080/092434 53.2010 .486589

Levin, B. (2010b). Leadership for evidence-informed education. School Leadership er Management, 30(4), 303-315. https://doi.org/10.1080/13632434.2010.497483

Levine, D. U., \& Lezotte, L. W. (1990). Unusually effective schools: A review and analysis of research and practice. Madison, WI: National Center for Effective Schools Research and Development.

Lezotte, L. (1989). School improvement based on the effective schools research. International Journal of Educational Research, 13(7), 815-825. https://doi. org/10.1016/0883-0355(89)90031-1

Lim, L. (2013). Meritocracy, elitism, and egalitarianism: A preliminary and provisional assessment of Singapore's primary education review. Asia Pacific Journal of Education, 33(1), 1-14. https://doi.org/10.1080/02188791.2012.711294

Lingard, B. (2007). Pedagogies of indifference. International Journal of Inclusive Education, 11(3), 245-266. https://doi.org/10.1080/13603110701237498

Linnakyla, P., Malin, A., \& Taube, K. (2004). Factors behind low reading literacy achievement. Scandinavian Journal of Educational Research, 48(3), 231-249. https://doi.org/10.1080/00313830410001695718 
Loucks-Horsley, S., Hewson, P. W., Love, N., \& Stiles, K. E. (1998). Designing professional development for teachers of science and mathematics. Thousand Oaks, CA: Corwin. https://doi.org/10.1080/13603110701237498

Louis, K. S. (1994). Beyond “managed change:” Rethinking how schools improve. School Effectiveness and School Improvement, 5(1), 2-24.

Lundberg, C. (1989). On organizational learning: Implications and opportunities for expanding organizational development. In R. W. Woodman \& W. A. Passmore (Eds.), Research in organizational change and development (Vol. 3, pp. 61-82). Greenwich, CT: JAI.

MacBeath, J. (1999). Schools must speak for themselves: The case for SSE. London: Routledge.

MacBeath, J., \& Mortimore, P. (2001). Improving school effectiveness. Buckingham, UK: Open University Press.

MacDonald, B. (1991). Critical introduction from innovation to reform: A framework for analysing change. In J. Rudduck (Ed.), Innovation and change: Developing involvement and understanding (pp. 1-13). Milton Keynes: Open University Press.

Marks, G. N., Cresswell, J., \& Ainley, J. (2006). Explaining socioeconomic inequalities in student achievement: The role of home and school factors. Educational Research and Evaluation: An International Journal on Theory and Practice, 12(2), 105-128. https://doi.org/10.1080/13803610600587040

Marsh, H. (2008). Big-fish-little-pond-effect: Total long-term negative effects of school-average ability on diverse educational outcomes over 8 adolescent/early adult years. International Journal of Psychology, 43(3-4), 53-54.

Marsh, H. W., \& Craven, R. G. (2006). Reciprocal effects of self-concept and performance from a multidimensional perspective: Beyond seductive pleasure and unidimensional perspectives. Perspectives on Psychological Science, 1(2), 133-163. https://doi.org/10.1111/j.1745-6916.2006.00010.x

Marsh, H. W., \& Parker, J. W. (1984). Determinants of student self-concept: Is it better to be a large fish in a small pond even if you don't learn to swim as well? Journal of Personality and Social Psychology, 47(1), 213-231. https://doi. org/10.1037/0022-3514.47.1.213

Maslowski, R. (2003). School culture and school performance: An explorative study into the organisational culture of secondary schools and their effects. Enschede: Twente University Press.

McCormack-Larkin, M. (1985). Ingredients of a successful school effectiveness project. Educational Leadership, 42(6), 31-37.

McCoy, S. K., \& Major, B. (2007). Priming meritocracy and the psychological justification of inequality. Journal of Experimental Social Psychology, 43(3), 341-351. https://doi.org/10.1016/j.jesp.2006.04.009

McTaggart, R. (1997). Participatory action research. Albany, NY: State University of New York Press.

Mejia-Rodriguez, A. M., \& Kyriakides, L. (2019). What makes countries more effective than others in promoting quality and equity in education? A systematic review of the literature. Paper presented at the European Conference for Educational Research 2019, Hamburg, Germany.

Merki, K. M., Rechsteiner, U. G., Rickenbacher, A., \& Wullschleger, A. (2019, August). Cooperative regulation activities of teachers, analysed based on time-sampling data. Paper presented at the Invited Symposium SIG 23 of the 18th Biennial Conference of EARLI, 'Social Interactions in School Improvement and their Relation to Instruction and Teachers' and Students' Learning', RWTH Aachen, Germany. 
Messick, S. (1996). Bridging cognition and personality in education: The role of style in performance and development. European Journal of Personality, 10(5), 353-376. https://doi.org/10.1002/(SICI)1099-0984(199612)10:5<353:: AID-PER268>3.0.CO;2-G

Meuret, D., \& Morlaix, S. (2003). Conditions of success of a school's self-evaluation: Some lessons of a European experience. School Effectiveness and School Improvement, 14(1), 53-71. https://doi.org/10.1076/sesi.14.1.53.13867

Micklewright, J., \& Schnepf, S. V. (2007). Inequality of learning in industrialized countries. In S. P. Jenkins \& J. Micklewright (Eds.), Inequality and poverty reexamined (pp. 129-45). Oxford: Oxford University Press.

Mijs, D., Houtveen, T., Wubells, T., \& Creemers, B. P. M. (2005, January). Is there empirical evidence for school improvement? Paper presented at the ICSEI 2005 Conference, Barcelona, Spain.

Miles, M. (1993). 40 years of change in schools: Some personal reflections. Educational Administration Quarterly, 29(2), 213-248. https://doi.org/10.1177/001 3161X93029002006

Mintrop, H., \& Trujillo, T. (2007). The practical relevance of accountability systems for school improvement: A descriptive analysis of California schools. Educational Evaluation and Policy Analysis, 29(4), 319-352. https://doi.org/10.3102/ 0162373707309219

Mintzberg, H. (1979). The structuring of organizations. Englewood Cliffs, NJ: Prentice-Hall.

Mohammadpour, E., \& Ghafar, M. N. A. (2014). Mathematics achievement as a function of within- and between-school differences. Scandinavian Journal of Educational Research, 58(2), 189-221. https://doi.org/10.1080/00313831.2012.7 25097

Monk, D. H. (1992). Education productivity research: An update and assessment of its role in education finance reform. Educational Evaluation and Policy Analysis, 14(4), 307-332. https://doi.org/10.3102/01623737014004307

Morgan, G. (1986). Images of organizations. Beverly Hills, CA: Sage.

Mortimore, P. (1991). School effectiveness research: Which way at the crossroads? School Effectiveness and School Improvement, 2(3), 213-229. https://doi. org/10.1080/0924345910020304

Mortimore, P., Sammons, P., Stoll, L., Lewis, D., \& Ecob, R. (1988). School matters: The junior years. Shepton Mallett: Open Books.

Mosteller, F., \& Boruch, R. (2002). Evidence matters: Randomized trials in education research. Washington, DC: Brookings.

Muijs, D. (2008). Widening opportunities? A case study of school-to-school collaboration in a rural district. Improving Schools, 11(1), 61-73. https://doi. org/10.1177/1365480207086755

Muijs, D. (2017). Can schools reduce bullying? The relationship between school characteristics and the prevalence of bullying behaviours. British Journal of Educational Psychology, 87(2), 255-272. https://doi.org/10.1111/bjep.12148

Muijs, D., \& Reynolds, D. (2000). School effectiveness and teacher effectiveness in mathematics: Some preliminary findings from the evaluation of the mathematics enhancement programme (primary). School Effectiveness and School Improvement, 11(3), 273-303. https://doi.org/10.1076/0924-3453(200009)11:3;1-G;FT273

Muijs, D., \& Reynolds, D. (2001). Effective teaching: Evidence and practice. London: Sage. 
Muijs, R. D., Kyriakides, L., van der Werf, G., Creemers, B. P. M., Timperley, H., \& Earl, L. (2014). State of the art-teacher effectiveness and professional learning. School Effectiveness and School Improvement, 25(2), 231-256. https://doi.org/ 10.1080/09243453.2014.885451

Murphy, J., \& Beck, L. (1995). School-based management as school reform: Taking stock. Thousand Oaks, CA: Corwin.

Murphy, J. F., Weil, M., Hallinger, P., \& Mitman, A. (1982). Academic press: Translating high expectations into school policies and classroom practices. Educational Leadership, 40(3), 22-26.

Nachbauer, M., \& Kyriakides, L. (2020). A review and evaluation of approaches to measure equity in educational outcomes. School Effectiveness and School Improvement, 31(2), 306-331. https://doi.org/10.1080/09243453.2019.1672757

Nakou, I. (2000). Elementary school teachers' representations regarding school problem behaviour: Problem children in talk. Educational and Child Psychology, 17(4), 91-106.

Nansel, T. R., Overpeck, M., Pilla, R. S., Ruan, W. J., Simons-Morton, B., \& Scheidt, P. (2001). Bullying behaviours among USA youth: Prevalence and association with psychosocial adjustment. Journal of the American Medical Association, 285(16), 2094-2100. https://doi.org/10.1001/jama.285.16.2094

Nevo, D. (1995). School-based evaluation: A dialogue for school improvement. Oxford: Pergamon Press.

Noble, T. (2004). Integrating the revised Bloom's taxonomy with multiple intelligence: A planning tool for curriculum differentiation. Teachers College Records, 106(1), 193-211.

Nuttall, D., Goldstein, H., Prosser, R., \& Rasbach, J. (1989). Differential school effectiveness International Journal of Educational Research, 13(7), 769-776. https://doi.org/10.1016/0883-0355(89)90027-X

OECD. (2010a). PISA 2009 results: Overcoming social background: Equity in learning opportunities and outcomes (Vol. II). Paris, France: OECD.

OECD. (2010b). PISA 2009 results: What students know and can do: Student performance in reading, mathematics and science (Vol. I). Paris, France: OECD.

OECD. (2012). Equity and quality in education: Supporting disadvantaged students and schools. Paris: OECD Publishing. Available in http://dx.doi. org/10.1787/9789264130852-en

OECD. (2013). PISA 2012 results: Excellence through equity: Giving every student the chance to succeed. Paris, France: OECD.

Opdenakker, M. C., \& Van Damme, J. (2006). Differences between secondary schools: A study about school context, group composition, school practice, and school effects with special attention to public and Catholic schools and types of schools. School Effectiveness and School Improvement, 17(1), 87-117. https://doi. org/10.1080/09243450500264457

Ottesen, E. (2007). Reflection in teacher education. Reflective Practice, 8(1), 31-46. https://doi.org/10.1080/14623940601138899

Paget, C. (2018). Exploring school resource and teacher qualification policies, their implementation and effects on schools and students' educational outcomes in Brazil. Unpublished doctoral dissertation. University of Oxford, Department of Education.

Pajares, F. (1999). Current directions in self-efficacy research. In M. Maehr, \& P. R. Pintrich (Eds.), Advances in motivation and achievement (pp. 1-49). Greenwich, CT: JAI Press. 
Pajares, F., \& Schunk, D. H. (2001). Self-beliefs and school success: Self-efficacy, self-concept, and school achievement. In R. Riding and S. Rayner (Eds.), Perception (pp. 239-266). London: Ablex Publishing.

Palardy, G. J. (2015). Classroom-based inequalities and achievement gaps in first grade: The role of classroom context and access to qualified and effective teachers. Teachers College Record, 117(2), 1-48.

Palardy, G. J., \& Rumberger, R. W. (2008). Teacher effectiveness in the first grade: The importance of background qualifications, attitudes, and instructional practices for student learning. Educational Evaluation and Policy Analysis, 30(2), 111-140. https://doi.org/10.3102/0162373708317680

Panayiotou, A., Kyriakides, L., \& Creemers, B. P. M. (2016). Testing the validity of the dynamic model at school level: A European study. School leadership and management, 36(1), 1-20. https://doi.org/10.1080/13632434.2015.1107537

Panayiotou, A., Kyriakides, L., Creemers, B. P. M., McMahon, L., Vanlaar, G., Pfeifer, M., . . . \& Bren, M. (2014). Teacher behavior and student outcomes: Results of a European study. Educational Assessment, Evaluation and Accountability, 26(1), 73-93.

Paquette, J. (1998). Equity in educational policy: A priority in transformation or in trouble? Journal of Education Policy, 13(1), 41-61. https://doi.org/10.1080/ 0268093980130104

Parada, R. H., Craven, R. G., \& Marsh, H. W. (2008). The beyond bullying secondary program: An innovative program empowering teachers to counteract bullying in schools. In H. W. Marsh, R. G. Craven, \& D. M. McInerney (Eds.), Self-processes, learning, and enabling human potential: Dynamic new approaches (Vol. 3, pp. 373426). Charlotte, NC: Information Age Publishing.

Paris, S. G., \& Paris, A. H. (2001). Classroom applications of research on self-regulated learning. Educational Psychologist, 36(2), 89-101. https://doi.org/10.1207/ S15326985EP3602_4

Patton, M. Q. (1991). Qualitative evaluation and research methods. London: SAGE. Pellegrino, J. W. (2004). Complex learning environments: Connecting learning theory, Instructional design, and technology. In N. M. Seel \& S. Dijkstra (Eds.), Curriculum, plans, and processes in instructional design (pp. 25-49). Mahwah, NJ: Lawrence Erlbaum Associates.

Preskill, H., Zuckerman, B., \& Matthews, B. (2003). An exploratory study of process use: Findings and implications for future research. American Journal of Evaluation, 24(4), 423-442. https://doi.org/10.1177/109821400302400402

Psacharopoulos, G. (2007). The costs of school failure: A feasibility study. European Expert Network on Economics of Education (EENEE) Analytical Report No. 2 prepared for the European Commission. Retrieved from www.eenee.de/eeneeHome/EENEE/Analytical-Reports.html

Purkey, S. C., \& Smith, M. S. (1983). Effective schools: A review. Elementary School Journal, 83(4), 427-452. https://doi.org/10.1086/461325

Ralph, J. H., \& Fennessey, J. (1983). Science or reform: Some questions about the effective schools model. Phi Delta Kappan, 64(10), 689-694.

Ramsay, P. D. K., Sneddon, D. G., Grenfell, J., \& Ford, I. (1982). Successful versus unsuccessful schools: A South Auckland study. Australia and New Zealand Journal of Sociology, 19(1), 217-234. 
Ray, A. (2006). School value added-measures in England: A paper for the OECD project on the development of value-added models in education systems. London: Department of Education Skills.

Redding, S. (2006). The mega system: Deciding. learning. connecting. A bandbook for continuous improvement within a community of the school. Lincoln, IL: Academic Development Institute.

Reezigt, G. J., \& Creemers, B. P. M. (2005). A comprehensive framework for effective school improvement. School Effectiveness and School Improvement, 16(4), 407-424. https://doi.org/10.1080/09243450500235200

Reezigt, G. J., Guldemond, H., \& Creemers, B. P. M. (1999). Empirical validity for a comprehensive model on educational effectiveness. School Effectiveness and School Improvement, 10(2), 193-216. https://doi.org/10.1076/sesi.10.2.193.3503

Reid, K., Hopkins, D., \& Holly, P. (1987). Towards the effective school. Oxford. Blackwell.

Renihan, F. I., \& Renihan, P. J. (1989). School improvement: Second generation issues and strategies. In B. P. M. Creemers, T. A. Peters \& D. Reynolds (Eds.), School effectiveness and school improvement (pp. 365-377). Amsterdam/Lisse: Swets \& Zeitlinger.

Reynolds, A. J., \& Walberg, H. J. (1990). A structural model of educational productivity. DeKalb, IL: Northern Illinois University.

Reynolds, D. (1991). Changing Ineffective Schools. In M. Ainscow (Ed.), Effective Schools for all (pp. 92-105). London: David Fulton.

Reynolds, D. (1996). Turning around ineffective schools: Some evidence and some speculations. In J. Gray, D. Reynolds, C. Fitz-Gibbon, \& D. Jesson (Eds.), Merging traditions: The future of research on school effectiveness and school improvement (pp. 150-165). London: Cassell.

Reynolds, D., Hopkins, D., \& Stoll, L. (1993). Linking school effectiveness knowledge and school improvement practice: Towards a synergy. School Effectiveness and School Improvement, 4(1), 37-58. https://doi.org/10.1080/0924345930040103

Reynolds, D., Sammons, P., De Fraine, B., Van Damme, J., Townsend, T., Teddlie, C., \& Stringfield, S. (2014). Educational effectiveness research (EER): A state-ofthe-art review. School Effectiveness and School Improvement, 25(2), 197-230. https:// doi.org/10.1080/09243453.2014.885450

Reynolds, D., \& Stoll, L. (1996). Merging school effectiveness and school improvement: The knowledge base. In D. Reynolds, R. Bollen, B. Creemers, D. Hopkins, L. Stoll, \& N. Lagerweij (Eds.), Making good schools: Linking school effectiveness and school improvement (pp. 94-112). London: Routledge.

Reynolds, D., Stringfield, S., \& Schaffer, E. (2006). The High Reliability Schools Project: Some preliminary results and analyses In J. Chrispeels \& A. Harris (Eds.), Improving schools and educational systems (pp. 56-76). London: Routledge.

Reynolds, D., Teddlie, C., Hopkins, D., \& Stringfield, S. (2000). Linking school effectiveness and school improvement. In C. Teddlie \& D. Reynolds (Eds.), The international handbook of school effectiveness research (pp. 206-231). London: Falmer Press.

Richardson, V., \& Anders, P. (1994). Staff development and the study of teacher change. In V. Richardson (Ed.), A theory of teacher change and the practice of staff development (pp. 159-180). New York: Teachers College Press.

Rigby, K., Smith, P. K., \& Pepler, D. (2005). Bullying in schools: How successful can interventions be? Cambridge: Cambridge University Press. 
Robson, C. (1993). Real world research. Oxford: Blackwell.

Rose, D. J., \& Church, R. J. (1998). Learning to teach: The acquisition and maintenance of teaching skills. Journal of Behavioral Education, 8(1), 5-35. https:// doi.org/10.1023/A:102286060

Rosenshine, B. (1976). Classroom instruction. In N. L. Gage (Ed.), The psychology of teaching methods: The seventy-fifth yearbook of the National Society for the Study of Education (pp. 335-371). Chicago, IL: University of Chicago Press.

Rosenshine, B. (1983). Teaching functions in instructional programs. The Elementary School Journal, 83(4), 335-351. https://doi.org/10.1086/461321

Rosenshine, B., \& Furst, N. (1973). The use of direct observation to study teaching. In R. M. W. Travers (Ed.), Second handbook of research on teaching. Chicago, IL: Rand McNally.

Rosenshine, B., \& Stevens, R. (1986). Teaching functions. In M. C. Wittrock (Ed.), Handbook of research on teaching (3rd ed., pp. 376-391). New York: Macmillan.

Rowan, B., Bossart, S. T., \& Dwyer, D. C. (1983). Research on effective schools. A cautionary note. Educational Researcher, 12(4), 24-32. https://doi. org/10.3102/0013189X012004024

Rowan, B., Correnti, R., Miller, R. J., \& Camburn, E. M. (2009). School improvement by design: Lessons from a study of comprehensive school reform programs. In G. Sykes \& B. Schneider (Eds.), Handbook on educational policy research (pp. 637-651). London: Routledge.

Rutter, M., Maughan, B., Mortimore, P., Ouston, J., \& Smith, A. (1979). Fifteen thousand hours: Secondary schools and their effects on children. Cambridge, MA: Harvard University Press.

Sackney, L. (1989). School effectiveness and improvement: The Canadian scene. In D. Reynolds, B. Creemers, \& T. Peters (Eds.), School effectiveness and improvement. Groningen: RION.

Salomon, G. (1979). Interaction of media, cognition and learning. San Francisco, CA: Jossey Bass.

Sammons, P. (2008). Zero tolerance of failure and New Labour approaches to school improvement in England. Oxford Review of Education, 34(6), 651-664. https:// doi.org/10.1080/03054980802518847

Sammons, P. (2009). The dynamics of educational effectiveness: A contribution to policy, practice and theory in contemporary schools. School Effectiveness \& School Improvement, 20(1), 123-129. https://doi.org/10.1080/09243450802664321

Sammons, P. (2010). Equity and educational effectiveness. In P. Peterson, E. Baker, \& B. McGaw (Eds.), International encyclopedia of education (pp. 51-57). Oxford: Elsevier.

Sammons, P., Hillman, J., \& Mortimore, P. (1995). Key characteristics of effective schools: A review of school effectiveness research. London: Office for Standards in Education and Institute of Education.

Sammons, P., Power, S., Elliot, K., Campbell, C., Robertson, P., \& Whitty, G. (2003). New community schools in Scotland: Final report-national evaluation of the pilot phase. Edinburgh: Scottish Executive Education Department.

Sammons, P., Toth, K., \& Sylva, K. (2018). The drivers of academic success for "bright" but disadvantaged students: A longitudinal study of AS and A-level outcomes in England. Studies in Educational Evaluation, 57, 31-41. https://doi. org/10.1016/j.stueduc.2017.10.004 
Sampson, S. O., \& Bradley, K. D. (2004). Measuring factors impacting educator supply and demand: An argument for Rasch analysis. Paper presented at the American Educational Research Association Annual Meeting, San Diego, CA.

Sanders, W. L., \& Horn, S. P. (1994). The Tennessee value-added assessment system (TVAAS): Mixed-model methodology in educational assessment. Journal of Personnel Evaluation in Education, 8(1), 299-311.

Savery, J. R., \& Duffy, T. M. (1995). Problem-based learning: An instructional model and its constructivist framework. Educational Technology, 35(5), 31-38.

Scheerens, J. (1992). Effective schooling: Research, theory and practice. London: Cassell.

Scheerens, J. (1993). Basic school effectiveness research: Items for a research agenda. School Effectiveness and School Improvement, 4(1), 17-36. https://doi. org/10.1080/0924345930040102

Scheerens, J. (1994). The school level context of instructional effectiveness: A comparison between school effectiveness and restructuring models. Tijdschrift voor Onderwijsresearch, 19(1), 26-39.

Scheerens, J. (2013). The use of theory in school effectiveness research revisited. School Effectiveness and School Improvement, 24(1), 1-38. https://doi.org/10.108 0/09243453.2012.691100

Scheerens, J. (2014). School, teaching, and system effectiveness: Some comments on three state-of-the-art reviews. School Effectiveness and School Improvement, 25(2), 282-290. https://doi.org/10.1080/09243453.2014.885453

Scheerens, J. (2016). Educational effectiveness and ineffectiveness: A critical review of the knowledge base. Dordrecht, the Netherlands: Springer. https://doi. org/10.1007/978-94-017-7459-8

Scheerens, J., \& Bosker, R. J. (1997). The foundations of educational effectiveness. Oxford: Pergamon.

Scheerens, J., \& Creemers, B. P. M. (1989). Conceptualizing school effectiveness. International Journal of Educational Research, 13(7), 691-706. https://doi. org/10.1016/0883-0355(89)90022-0

Scheerens, J., \& Demeuse, M. (2005). The theoretical basis of the effective school improvement model (ESI). School Effectiveness and School Improvement, 16(4), 373-385. https://doi.org/10.1080/09243450500234567

Scheerens, J., Glas, C., \& Thomas, S. (2003). Educational evaluation, assessment and monitoring: A systemic approach. Lisse: Swets \& Zweitlinger Publishers.

Scheerens, J., Luyten, H., van den Berg, S. M., \& Glas, C. A. (2015). Exploration of direct and indirect associations of system-level policy-amenable variables with reading literacy performance. Educational Research and Evaluation, 21(1), 15-39. https://doi.org/10.1080/13803611.2015.1008520

Scheerens, J., Seidel, T., Witziers, B., Hendriks, M., \& Doornekamp, G. (2005). Positioning and validating the supervision framework. Enschede/Kiel: University of Twente, Department of Educational Organisational and Management.

Schmidt, W. H. (2018). Opportunity to learn and equity of education. Paper presented at the "Quality and Equity of Schooling" Symposium of the Royal Swedish Academy of Sciences and The Wenner-Gren Foundations, Stockholm, 12-15 September.

Schmidt, W. H., Jakwerth, P., \& McKnight, C. C. (1998). Curriculum sensitive assessment: Content does make a difference. International Journal of Educational Research, 29(6), 503-527. https://doi.org/10.1016/S0883-0355(98)00045-7 
Schmidt, W., \& Valverde, G. A. (1995). National policy and cross national research: United States participation in the Third International and Science Study. East Lansing, MI: Michigan State University.

Schoenfeld, A. H. (1998). Toward a theory of teaching in context. Issues in Education, 4(1), 1-94. https://doi.org/10.1016/S1080-9724(99)80076-7

Schon, D. A. (1971). Beyond the stable state. Harmondsworth: Penguin.

Schon, D. A. (1983). The reflective practitioner: How professionals think in action. New York: Basic Books.

Scott, C., \& Dinham, S. (2002). The beatings will continue until quality improves: Carrots and sticks in the search for educational improvement. Teacher Development, 6(1), 15-31. https://doi.org/10.1080/13664530200200154

Sebastian, J., Allensworth, E., \& Huang, H. (2016). The role of teacher leadership in how principals influence classroom instruction and student learning. American Journal of Education, 123(1), 69-108. https://doi.org/10.1086/688169

Senge, P. (1990). The fifth discipline: The art and practice of the learning organization. New York: DoubleDay.

Shadish, W. R., Cook, T. D., \& Campbell, D. T. (2002). Experimental and quasi-experimental designs for generalized causal inference. Boston, MA: Houghton-Mifflin.

Shaw, K. M., \& Replogle, E. (1996). Challenges in evaluating school-linked services-Toward a more comprehensive evaluation framework. Evaluation Review, 20(4), 424-469. https://doi.org/10.1177/0193841X9602000404

Shields, P. M., Marsh, J., \& Adelman, N. E. (1998). The SSI's impacts on classroom practice. Menlo Park, CA: SRI International.

Shipman, M. D. (1985). Ethnography and educational policy-making. In R. G. Burgess (Ed.), Field methods in the study of education. London: Falmer Press.

Simons, H. (1990, November). Evaluation and the reform of schools. In The evaluation of educational programmes: Methods, uses and benefits. Report of the Education Research Workshop held in North Berwick (Scotland), 22-25 November 1998 (pp. 46-64). Amsterdam/Lisse, The Netherlands: Swets \& Zeitlinger.

Simons, R. J., van der Linden, J., \& Duffy, T. (2000). New learning: Three ways to learn in a new balance. In R. J. Simons, J. van der Linden, \& T. Duffy (Eds.), New learning (pp. 1-20). Dordrecht, The Netherlands: Kluwer.

Sirin, S. R. (2005). Socioeconomic status and academic achievement: A meta-analytic review of research. Review of Educational Research, 75(3), 417-453. https://doi. org $/ 10.3102 / 00346543075003417$

Slater, R. O., \& Teddlie, C. (1992). Toward a theory of school effectiveness and leadership. School Effectiveness and School Improvement, 3(4), 247-257. https:// doi.org/10.1080/0924345920030402

Slavin, R. E. (1983). When does cooperative learning increase student-achievement. Psychological Bulletin, 94(3), 429-445. https://doi.org/10.1037/0033-2909. 94.3.429

Slavin, R. E. (1987). Ability grouping and student achievement in elementary schools: A best-evidence synthesis. Review of Educational Research, 57(3), 293-326. https:// doi.org/10.1037/0033-2909.94.3.429

Slavin, R. E. (1989). Class size and student achievement: Small effects of small classes. Educational Psychologist, 24(1), 99-110. https://doi.org/10.1207/ s15326985ep2401_4 
Slavin, R. E. (1996). Education for all. Lisse: Swets \& Zeitlinger.

Slavin, R. E. (2002). Evidence-based education policies: Transforming educational practice and research. Educational Researcher, 31(7), 15-21. https://doi. org/10.3102/0013189X031007015

Slavin, R. E., \& Cheung, A. C. (2017). Lessons Learned from Large-Scale Randomized Experiments. Journal of Education for Students Placed at Risk (JESPAR), 22(4), 253-259. https://doi.org/10.1080/10824669.2017.1360774

Slavin, R. E., \& Cooper, R. (1999). Improving intergroup relations: Lessons learned from cooperative learning programs. Journal of Social Issues, 55(4), 647-663. https://doi.org/10.1111/0022-4537.00140

Slavin, R. E., Lake, C., Davis, S., \& Madden, N. (2011). Effective programs for struggling readers: A best-evidence synthesis. Educational Research Review, 6(1), 1-26. https://doi.org/10.1016/j.edurev.2010.07.002

Slavin, R. E., Lake, C., \& Groff, C. (2009). Effective programs in middle and high school mathematics: A best-evidence synthesis. Review of Educational Research, 79(2), 839-911. https://doi.org/10.3102/0034654308330968

Slee, P. T. (1994). Situational and interpersonal correlates of anxiety associated with peer victimization. Child Psychiatry and Human Development, 25, 97-107. https:// doi.org/10.1007/BF02253289

Smith, D., \& Hatton, N. (1992). Towards reflection in teacher education: What counts as evidence? Paper presented at the Annual Conference of the Australian Association for Research in Education, Deakin University, November 1992.

Smith, J. D., Schneider, B., Smith, P. K., \& Ananiadou, K. (2004). The effectiveness of whole-school anti-bullying programs: A synthesis of evaluation research. School Psychology Review, 33(4), 548-561. https://doi.org/10.1080/02796015.2004.120 86267

Smith, P., Morita, Y., Junger-Tas, J., Olweus, D., Catalano, R., \& Slee, P. (Eds.). (1999). The nature of school bullying: A cross-national perspective. London: Routledge.

Smylie, M. A., Lazarus, V., \& Brownlee-Conyers, J. (1996). Instructional outcomes of school-based participative decision making. Educational Evaluation and Policy Analysis, 18(3), 181-198. https://doi.org/10.3102/01623737018003181

Snyder, J., Bolin, F., \& Zumwalt, K. (1992). Curriculum implementation. In P. W. Jackson (Ed.), Handbook of research on curriculum (pp. 402-435). New York: Macmillan.

Somekh, B. (1995). The contribution of action research in social endeavours: A position paper on action research methodology. British Educational Research Journal, 21(3), 339-355. https://doi.org/10.1080/0141192950210307

Southworth, G. (2002). Instructional leadership in schools: Reflections and empirical evidence. School Leadership \& Management, 22(1), 73-91. https://doi. org/10.1080/13632430220143042

Spencer, M. B., Noll, E., \& Cassidy, E. (2000). Monetary incentives in support of academic achievement-Results of a randomized field trial involving high-achieving, low-resource, ethnically diverse urban adolescents. Evaluation Review, 29(3), 199222. https://doi.org/10.1177/0193841X04273329

Spillane, J. P. (2005). Primary school leadership practice: How the subject matters. School Leadership and Management, 25(4), 383-397. https://doi.org/10.1080/ 13634230500197231 
Sprinthall, N., Reiman, A., \& Thies-Sprinthall, L. (1996). Teacher professional development. In J. Sikula, T. Buttery, \& E. Guyton (Eds.), Handbook of research on teacher education (2nd ed., pp. 666-703). New York: Macmillan.

Squires, D. A., Hewitt, W. G., \& Segars, J. K. (1983). Effective schools and classrooms: A research based perspective. Alexandria, VA: Association for Supervision and Curriculum Development.

Sternberg, R. J. (1988). Mental self-government: A theory of intellectual styles and their development. Human Development, 31(4), 197-224. https://doi. org/10.1159/000275810

Sternberg, R. J. (1994). Allowing for thinking styles. Educational Leadership, 52(3), 36-39.

Sternberg, R. J., Forsythe, G. B., Hedlund, J., Horvath, J. A., Wagner, R. K., Williams, W. M., . . . \& Grigorenko, E. L. (2000). Practical intelligence in everyday life. New York: Cambridge University Press.

Stevens, V., De Bourdeaudhuij, I., \& Van Oost, P. (2000). Bullying in Flemish schools: An evaluation of anti-bullying intervention in primary and secondary schools. British Journal of Educational Psychology, 70(2), 195-210. https://doi. org/10.1348/000709900158056

Stipek, D. (2004). Teaching practices in kindergarten and first grade: Different strokes for different folks. Early Childhood Research Quarterly, 19(4), 548-568. https:// doi.org/10.1016/j.ecresq.2004.10.010

Stoiber, K. (1991). The effect of technical and reflective instruction on pedagogical reasoning and problem solving. Journal of Teacher Education, 42(2), 131-139. https://doi.org/10.1177/002248719104200206

Stoll, L., \& Fink, D. (1989). An effective schools project: The Halton Approach. In D. Reynolds, B. Creemers, \& T. Peters (Eds.), School effectiveness and improvement. Groningen: RION.

Stoll, L., \& Fink, D. (1992). Effecting school change: The Halton Approach. School Effectiveness and School Improvement, 3(1), 19-4l. https://doi.org/10.1080/ 0924345920030103

Stoll, L., \& Fink, D. (1994). School effectiveness and school improvement: Voices from the field. School Effectiveness and School Improvement, 5(2), 149-178. https:// doi.org/10.1080/0924345940050203

Stoll, L., Reynolds, D., Creemers, B., \& Hopkins, D. (1996). Merging school effectiveness and school improvement: Practical examples. In D. Reynolds, R. Bollen, B. Creemers, D. Hopkins, L. Stoll, \& N. Lagerweij (Eds.), Making good schools (pp. 113-147). London and New York: Routledge.

Strand, S. (2010). Do some schools narrow the gap? Differential school effectiveness by ethnicity, gender, poverty, and prior achievement. School Effectiveness and School Improvement, 21(3), 289-314. https://doi.org/10.1080/09243451003732651

Stringfield, S. (1994). A model of elementary school effects. In D. Reynolds, B. P. M. Creemers, P. S. Nesselrodt, E. C. Schaffer, S. Stringfield, \& C. Teddlie (Eds.), Advances in school effectiveness research and practice (pp. 153-187). Oxford: Pergamon Press.

Stringfield, S. (1995). Attempting to enhance students' learning through innovative programs: The case for schools evolving into high reliability organisations. School Effectiveness and School Improvement, 6(1), 67-96. https://doi.org/10.1080/ 0924345950060104 
Stringfield, S. C., \& Slavin, R. E. (1992). A hierarchical longitudinal model for elementary school effects. In B. P. M. Creemers \& G. J. Reezigt (Eds.), Evaluation of educational effectiveness (pp. 35-69). Groningen: ICO.

Stufflebeam, D. L., \& Shinkfield, A. J. (1990). Systematic evaluation. Lancaster: Kluwer-Nijhoff.

Swearer, S. M., Espelage, D. L., \& Napolitano, S. A. (2009). Bullying prevention and intervention: Realistic strategies for schools. New York: Guilford Press.

Taggart, B., \& Sammons, P. (1999). Evaluating the impact of raising school standards initiative. In R. J. Bosker, B. P. M. Creemers, \& S. Stringfield (Eds.), Enhancing educational excellence, equity and efficiency: Evidence from evaluations of systems and schools in change (pp. 137-166). Dordrecht: Kluwer Academic Publishers.

Talbert, J. E. (2002). Professionalism and politics in high school teaching reform. Journal of Educational Change, 3(3/4), 339-363. https://doi. org/10.1023/A:1021229929671

Teddlie, C. (1994). The integration of classroom and school process data in school effectiveness research. In D. Reynolds et al. (Eds.), Advances in school effectiveness research and practice (pp. 111-133). Oxford: Pergamon.

Teddlie, C., \& Reynolds, D. (2000). The international handbook of school effectiveness research. London: Falmer Press.

Teddlie, C., \& Roberts, S. P. (1993, April). More clearly defining the field: A survey of subtopics in school effectiveness research. Paper presented at the Annual Meeting of the American Educational Research Association, Atlanta.

Teddlie, C., \& Stringfield, S. (1993). Schools make a difference: Lessons learned from a 10-year study of school effects. New York: Teachers College Press.

Telese, J. A. (2008). Teacher professional development in mathematics and student achievement: A NAEP 2005 analysis. Paper presented at the annual meeting of the School Science and Mathematics Association, Raleigh, NC, 13-15 November.

Thomas, G., \& Pring, R. (2004). Evidence-based practice in education. Buckingham, UK: Open University Press.

Thomas, S. (2001). Dimensions of secondary school effectiveness: Comparative analyses across regions. School Effectiveness and School Improvement, 12(3), 285-322. https://doi.org/10.1076/sesi.12.3.285.3448

Thomas, S., Kyriakides, L., \& Townsend, T. (2016). Educational effectiveness research in new, emerging and traditional contexts. In C. Chapman, D. Muijs, D. Reynolds, P. Sammons, \& C. Teddlie (Eds.). The Routledge international handbook of educational effectiveness and improvement (pp. 220-245). London: Routledge.

Thomas, S., Peng, W. J., \& Gray, J. (2007). Modelling patterns of improvement over time: Value added trends in English secondary school performance across ten cohorts. Oxford Review of Education, 33(3), 261-295. https://doi.org/10.1080/ 03054980701366116

Thrupp, M. (2001). Recent school effectiveness counter-critiques: Problems and possibilities. British Educational Research Journal, 27(4), 443-457. https://doi. org/10.1080/01411920120071452

Torney-Purta, J., Lehmann, R., Oswald, H., \& Schulz, W. (2001). Citizenship and education in twenty-eight countries: Civic knowledge and engagement at age fourteen. Amsterdam, the Netherlands: IEA.

Torres, R. T., \& Preskill, H. (2001). Evaluation and organizational learning: Past, present, and future. American Journal of Evaluation, 22(3), 387-395. https:// doi.org/10.1177/109821400102200316 
Townsend, T. (2007). International handbook of school effectiveness and improvement. Dordrecht, the Netherlands: Springer.

Trautwein, U., Koller, O., Schmitz, B., \& Baumert, J. (2002). Do homework assignments enhance achievement? A multilevel analysis in 7th-grade mathematics. Contemporary Educational Psychology, 27(1), 26-50. https://doi.org/10.1006/ ceps.2001.1084

Valverde, G. A., \& Schmidt, W. H. (2000). Greater expectations: Learning from other nations in the quest for "world-class standards" in US school mathematics and science. Journal of Curriculum Studies, 32(5), 651-687. https://doi.org/10.1080/ 00220270050116932

Van Damme, J., \& Bellens, K. (2017). Countries strive towards more quality and equity in education: Do they show success or failure? Evidence from TIMSS 2003 and 2011, for Grade 4. In M. Rosén, K. Yang Hansen, \& U. Wolff (Eds.), Cognitive abilities and educational achievement: Measurement and determinant. A festschrift in honor of Jan-Eric Gustafsson (pp. 127-148). Dordrecht: Springer. https:// doi.org/10.1007/978-3-319-43473-5_7

van den Ham, A. K., Niedermeyer, I., \& Heinze, A. (2017, September). A two-year study of textbook effects on German primary school students' mathematical competence. Paper presented at the 17th Biennial EARLI Conference 'Education in the Crossroads of Economy and Politics-Role of Research in the Advancement of Public Good', University of Tampere, Finland, 27 August-2 September.

van der Schaaf, M. F., \& Stokking, K. M. (2011). Construct validation of content standards for teaching. Scandinavian Journal of Educational Research, 55(3), 273289. https://doi.org/10.1080/00313831.2011.576878

van der Werf, G., Opdenakker, M-C., \& Kuyper, H. (2008). Testing a dynamic model of student and school effectiveness with a multivariate multilevel latent growth curve approach. School Effectiveness and School Improvement, 19(4), 447462. https://doi.org/10.1080/09243450802535216

Vanlaar, G., Kyriakides, L., Panayiotou, A., Vandecandelaere, M., McMahon, L., De Fraine, B., \& Van Damme, J. (2016). Do the teacher and school factors of the dynamic model affect high- and low-achieving student groups to the same extent? A cross-country study. Research Papers in Education, 31(2), 183-211. https://doi. org/10.1080/02671522.2015.1027724

Van Manen, M., \& Li, S. (2002). The pathic principle of pedagogical language. Teaching and Teacher Education, 18(2), 215-224. https://doi.org/10.1016/ S0742-051X(01)00065-8

Vanwynsberghe, G., Vanlaar, G., Van Damme, J., \& De Fraine, B. (2017). Long-term effects of primary schools on educational positions of students 2 and 4 years after the start of secondary education. School Effectiveness and School Improvement, 28(2), 167-190. https://doi.org/10.1080/09243453.2016.1245667

Verhaeghe, J. P., Vanlaar, G., Knipprath, H., De Fraine, B., \& Van Damme, J. (2018). Can group composition effects explain socioeconomic and ethnic achievement gaps in primary education? Studies in Educational Evaluation, 57, 6-15. https://doi. org/10.1016/j.stueduc.2017.07.006

Vermunt, J., \& Verschaffel, L. (2000). Process-oriented teaching. In R. J. Simons, J. van der Linden, \& T. Duffy (Eds.), New learning (pp. 209-225). Dordrecht, The Netherlands: Kluwer.

Visscher, A., \& Coe, R. (Eds.). (2002). School improvement through performance feedback. Lisse: Swets \& Zeitlinger. 
Walberg, H. (2007). Handbook on restructuring and substantial school improvement. Charlotte, NC: Information Age Publishers.

Walberg, H. J. (1984). Improving the productivity of America's schools. Educational Leadership, 41(8), 19-27.

Walberg, H. J. (1986). Syntheses of research on teaching. In M. C. Wittrock (Ed.), Handbook of research on teaching (3rd ed., pp. 214-229). New York: Macmillan.

Wang, L. Y., Victor, D. T. C., \& Neo, W. L. (2019). Studying the enactment of school-based curriculum development (SBCD) in Singapore. Educational Research, 61(3), 337-355. https://doi.org/10.1080/00131881.2019.1642120

Wang, W. C., \& Cheng, Y. Y. (2001). Measurement issues in screening outstanding teachers. Journal of Applied Measurement, 2(2), 171-186.

Wehrens, M. J. P. W., Kuyper, H., Dijkstra, P., Buunk, A. P., \& van der Werf, M. P. C. (2010). The long-term effect of social comparison on academic performance. European Journal of Social Psychology, 40(7), 1158-1171. https://doi.org/10.1002/ ejsp.706

Weiss, I. R., Montgomery, D. L., Ridgway, C. J., \& Bond, S. L. (1998). Local systemic change through teacher enhancement: Year three cross-site report. Chapel Hill, NC: Horizon Research, Inc.

White, K. (1982). The relation between socioeconomic status and academic achievement. Psychological Bulletin, 91(3), 461-481. https://doi.org/10.1037/ 0033-2909.91.3.461

Whitney, I., \& Smith, P. K. (1993). A survey of the nature and extent of bully/ victim problems in junior/middle and secondary schools. Educational Research, 35(1), 3-25. https://doi.org/10.1080/0013188930350101

Whitty, G. (2001). Education, social class and social exclusion. Journal of Education Policy, 16(4), 287-295. https://doi.org/10.1080/02680930110054308

Wiggins, G., \& McTighe, J. (1998). Understanding by design. Alexandria, VA: ASCD.

Wilson, S. J., Lipsey, M. W., \& Derzon, J. H. (2003). The effects of school-based intervention programs on aggressive behavior: A meta-analysis. Journal of Consulting and Clinical Psychology, 71(1), 136-149.

Witziers, B., Bosker, R. J., \& Krüger, M. L. (2003). Instructional leadership and student achievement: The elusive search for an association. Educational Administrative Quarterly, 39(3), 398-425. https://doi.org/10.1177/0013161X03253411

Woessmann, L. (2016). The importance of school systems: Evidence from international differences in student achievement. Journal of Economic Perspectives, 30(3), 3-32. https://doi.org/10.1257/jep.30.3.

Wößmann, L. (2003). Schooling resources, educational institutions and student performance: The international evidence. Oxford Bulletin of Economics and Statistics, 65(2), 117-170. https://doi.org/10.1111/1468-0084.00045

Wright, B. D., \& Linacre, J. M. (1989). Observations are always ordinal: Measurements, however, must be interval. Archives of Physical Measurement and Rehabilitation, 70(12), 857-860.

Wullschleger, A., Merki, K. M., Rechsteiner, U. G., Schori, N., \& Rickenbacher, A. (2019, August). Social interactions within school teams concerned with new ideas for teaching, teamwork and whole-school issues. Paper presented at the Invited Symposium SIG 23 of the 18th Biennial Conference of EARLI, 'Social Interactions in School Improvement and their Relation to Instruction and Teachers' and Students' Learning', RWTH Aachen, Germany. 
Xue, Y., \& Meisels, S. J. (2004). Early literacy instruction and learning in kindergarten: Evidence from the early childhood longitudinal study-Kindergarten class of 1998-1999. American Educational Research Journal, 41(1), 191-229. https:// doi.org/10.3102/00028312041001191

Yeh, S. S. (2009). The cost-effectiveness of raising teacher quality. Educational Research Review, 4(3), 220-232. https://doi.org/10.1016/j.edurev.2008.06.002

Yoon, K. S., Duncan, T., Lee, S. W. Y., Scarloss, B., \& Shapley, K. (2007). Reviewing the evidence on how teacher professional development affects student achievement (Issues and Answers Report, REL 2007 No. 033). Washington, DC: U.S. Department of Education, Regional Educational Laboratory Southwest.

Yoon, K. S., Garet, M., Birman, B., \& Jacobson, R. (2007). Examining the effects of mathematics and science professional development on teachers' instructional practice: Using professional development activity log. Washington, DC: Council of Chief State School Officers.

Zeichner, K. M. (1983). Alternative paradigms of teacher education. Journal of Teacher Education, 34(3), 3-9. https://doi.org/10.1177/002248718303400302

Zeichner, K. M. (1987). Preparing reflective teachers: An overview of instructional strategies which have been employed in preservice teacher education. International Journal of Educational Research, 11(5), 565-575.

Zhang, H., Chan, P. W. K., \& Boyle, C. (Eds.). (2014). Equality in education: Fairness and inclusion. Rotterdam: Sense Publishers.

Zhang, L. F. (2001). Do thinking styles contribute to academic achievement beyond self-rated abilities? The Journal of Psychology, 135(6), 621-638. https://doi. org/10.1080/00223980109603724

Zhang, L. F. (2002). Measuring thinking styles in addition to measuring personality traits? Personality and Individual Differences, 33(3), 445-458. https://doi. org/10.1016/S0191-8869(01)00166-0

Zhang, L. F. (2011). The developing field of intellectual styles: Four recent endeavours. Learning and Individual Differences, 21(3), 311-318. https://doi. org/10.1016/j.lindif.2010.11.018

Zhang, L. F., \& Sternberg, R. J. (1998). Thinking styles, abilities, and academic achievement among Hong Kong university students. Educational Research Journal, 13(1), 41-62. 